\title{
Small Intensely Fluorescent Cells in Culture: Role of Glucocorticoids and Growth Factors in Their Development and Interconversions with other Neural Crest Derivatives ${ }^{1}$
}

\author{
ALLISON J. DOUPE, PAUL H. PATTERSON, ${ }^{2}$ AND STORY C. LANDIS \\ Department of Neurobiology, Harvard Medical School, Boston, Massachusetts 02115
}

\begin{abstract}
The neural crest gives rise to a number of adrenergic derivatives, including sympathetic neurons and adrenal chromaffin cells, which contain catecholamines (CAs) but differ in other morphological and functional characteristics. Small intensely fluorescent (SIF) cells, which exist primarily as a minority cell population in autonomic ganglia, are a third cell type in the sympathoadrenal branch of the neural crest lineage. In some respects these cells appear intermediate in phenotype between sympathetic neurons and adrenal chromaffin cells. We established pure dissociated cell cultures of SIF cells from rat superior cervical ganglia (SCG) and used these to study the role of environmental factors in SIF cell development and the relationship of these cells to the other cell types of the sympathoadrenal lineage.

When cells from neonatal rat SCG were grown for 3 weeks in the presence of glucocorticoid and in the absence of nerve growth factor (NGF), pure cultures of SIF cells developed. The properties of the cells included (i) small cell size and the occasional presence of short neurites, (ii) intense CA histofluorescence and immunoreactivity for CA synthetic enzymes, (iii) synthesis and storage of $\mathrm{CA}$ from radioactive precursors, and (iv) characteristic ultrastructure. The concentration of the glucocorticoid and the presence or absence of non-neuronal cell factors influenced which types of SIF cells developed. In micromolar glucocorticoid most of the cells resembled adrenal chromaffin or type II SIF cells: they displayed immunohistochemically detectable phenylethanolamine- $\mathrm{N}$-methyltransferase (PNMT), synthesized and stored epinephrine, and contained large granular vesicles (100 to $300 \mathrm{~nm}$ ). When SCG cells were grown in $10^{-8} \mathrm{~m}$ hormone, many fewer SIF cells developed and a higher percentage of
\end{abstract}

Received September 4, 1984; Revised December 7, 1984

Accepted December 7, 1984

'A. J. D. valas a member of and was supported in part by the Harvard University Soclety of rellows, and in part by the Insurance Medical Scientist Scholarship Fund and the Prudential Life Insurtance Co. S. C. L. is an Established investigator of the American Heart Association, supported in part by the Massachusetts Affiliate. P. H. P. was a Rita Allen Foundation Scholar and a McKnight Foundation Neuroscience Development Awardee. We wish to thank Doreen MacDowell and John Fredieu for expert technical assistance, and Wendy Brooks, Joe Gagliardi, and Shirley Wilson for manuscript preparation. We also wish to thank Tom Fox for the generous use of his HPLC, equipment, and Jane Dodd, Jim Huettner, Tom Jessell, Bill Matthew, and Eve Wolinsky for helpful discussions of the manuscript.

${ }^{2}$ To whom correspondence should be addressed, at: Division of Biology, California Institute of Technology, Pasadena, CA 91125. these lacked PNMT immunoreactivity, had neurites, and contained vesicles of smaller mean diameter $(70$ to $130 \mathrm{~nm})$, similar to those of type I SIF cells in vivo. In the presence of conditioned medium (medium conditioned by non-neuronal cells) as well as glucocorticoid, virtually all of the cells morphologically resembled type I SIF cells. In the absence of glucocorticoid, no SIF cells were ever observed after 3 weeks in culture.

By following the development of CA histofluorescence and SIF cell ultrastructure in the cultures over time, we demonstrated that SIF cells were not present in large numbers in these cultures immediately after plating, but were induced from an apparently undifferentiated precursor by the hormonal environment, whereas most of the principal neurons died. When corticosteroid was subsequently withdrawn from mature SIF cell cultures and replaced by NGF, the SIF cells responded with neurite outgrowth and conversion into neurons. They increased in size, lost their intense cell body CA histofluorescence and large granular vesicles, and acquired characteristic neuronal ultrastructure including small clear vesicles and morphologically specialized synapses. Thus, there are cells in the SCG with the potential to become either SIF cells or neurons, and NGF and glucocorticoids influence this choice. As described in the preceding paper for adrenal chromaffin cells in NGF (Doupe, A. J., S. C. Landis, and P. H. Patterson (1985) J. Neurosci. 5: 2119-2142), type II SIF cells transiently acquired vesicles of SIF type I size during the conversion to neurons. Furthermore, when both NGF and corticosteroid were added to mature SIF cell cultures, many of the cells also assumed an intermediate phenotype resembling type I SIF cells.

The studies in this and the preceding paper provide evidence for a role of environmental factors in neural crest differentiation. Similar factors could act during normal development and may explain the characteristic localization and heterogeneity of these phenotypes in vivo. Moreover, the central position of type I SIF cells in the interconversions demonstrated in vitro and the morphological similarity of these cells to early sympathetic precursors suggest that SIF cells may normally be precursors to the entire autonomic lineage of the neural crest in vivo.

Sympathetic principal neurons and adrenal chromaffin cells are both neural crest derivatives. They synthesize and store catecholamines (CAs) but differ in a number of morphological and functional characteristics (Coupland, 1965a, b; Grillo, 1966; Grynszpan-Winograd, 1975). A variety of evidence suggests that the cellular and hormonal environment surrounding these cells during development plays an important role in generating the different phenotypes (see Doupe et al., 1985). There is a third cell type in the sympathoadrenal 
branch of the neural crest lineage, which is intermediate in a number of respects between the other two cell types. Small intensely fluorescent (SIF) cells, sometimes referred to as extraadrenal chromaffin cells, resemble adrenal chromaffin cells in that they have small (10 to $15 \mu \mathrm{m}$ ) cell bodies (Eranko and Harkonen, 1963, 1965; Norberg et al., 1966) packed with large CA storage granules (Grillo, 1966; Siegrist et al., 1966; Matthews and Raisman, 1969; Williams and Palay, 1969). In contrast, some SIF cells have neurites (Owman and Sjostrand, 1965; Norberg et al., 1966) and make synapses as do sympathetic neurons (Williams, 1967; Siegrist et al., 1968; Yokota, 1973; Taxi, 1979). SIF cells exist either as minority populations in autonomic ganglia, where they are usually clustered around blood vessels, or as small clusters of cells (paraganglia) along nerves and bloud vessets in the abdomen (McDonald and Blewett, 1981). There is a small population of SIF-like cells in the adrenal medulla, referred to as small granule chromaffin cells (Coupland et al., 1977, 1978). The carotid body, which has been shown by quail-chick grafts to be derived from rhombencephalic crest (Le Douarin and Teillet, 1974), also consists primarily of SIF cells (Kobayashi, 1971). Thus, SIF cells are derived from many axial levels of the neural crest and are widely distributed throughout the body.

How is this cell type generated during embryogenesis? It has been observed that there are more SIF cells earlier in development than later (Lempinen, 1964). This decrease in SIF cell numbers can be influenced by glucocorticoid hormones. Lempinen (1964) showed that the postnatal degeneration of certain extra-adrenal chromaffin tissues could be prevented with corticosteroid, and Eranko and colleagues (Eranko and Eranko, 1972; Eranko et al., 1972a) demonstrated that the supcrior cervical ganglia (SCG) of rats treated at birth with glucocorticoid subsequently had 10 times as many SIF cells as did untreated siblings. The mechanism of the hormone effect on the SCG is unknown: it could be due to prevention of SIF cell degeneration, induction of mitosis, or recruitment of cells from another population.

In contrast, the sympathetic neurons that surround most SIF cells in vivo depend on nerve growth factor (NGF) for their survival and differentiation. The effects of NGF on SIF cells are not known. The occasional SIF cells observed in cultures of embryonic chick sympathetic ganglia appeared to survive in the absence of NGF but grew processes more slowly than in the presence of the growth factor (Jacobowitz and Greene, 1974). Studies in vivo with NGF injections also suggested that some carotid body SIF cells might be NGF responsive (Aloe and Levi-Montalcini, 1980).

Another striking characteristic of SIF cells is their heterogeneity (see Taxi, 1979, for review). Their CA storage vesicles are of different sizes, and this variation forms the basis for one classification system of SIF cells in vivo: type II cells have granular vesicles with an average diameter similar to that of adrenal chromaffin granules (150 to 300 $\mathrm{nm}$ ), whereas type I SIF cells have smaller vesicles with an average diameter $(80$ to $100 \mathrm{~nm}$ ) intermediate between that of synaptic vesicles $(50 \mathrm{~nm}$ ) and chromaffin granules (cf. Siegrist et al., 1968; Matthews and Raisman, 1969; Taxi, 1979). The distribution of these cell types varies according to species and ganglia. Type I cells predominate in the rat SCG, for instance, but constitute only $30 \%$ of SIF cells in celiac-mesenteric ganglia (Lu et al., 1976). In contrast, only type li cells were observed in rał pelvic ganglia (Dail et al., 1975) and in guinea pig inferior mesenteric ganglia (Elfvin et al., 1975). The major CA stored by SIF cells also varies among species and among ganglia and even within the same ganglion. For instance, the predominant CA stored by the majority of SIF cells in the rat SCG is dopamine, although some SCG cells store norepinephrine (Bjorklund et al., 1970; Fuxe et al., 1971; Rybarczyck et al., 1976). in rat pelvic ganglia, most cells probably synthesize norepinephrine (Rybarczyck et al., 1976). In the guinea pig, most SCG SIF cells contain the synthetic enzymes for norepinephrine, whereas in the inferior mesenteric ganglion some SIF cells store predominantly epinephrine (Eltvin et al., 1975). It is not clear how this heterogeneity arises.
Many of the questions about SIF cell development and the potential role of environmental factors might be usefully addressed in cell culture. In the work described here, pure dissociated SIF cell cultures from rat SCG were eslablished and characterized. We then used these cultures to study the developmental roles of glucocorticoids, NGF, and conditioned media (CM). The findings in this and the preceding paper (Doupe et al., 1985) also shed light on the relationship between SIF cells and the other cell types of the sympathoadrenal lineage. Preliminary accounts of this work have appeared (Doupe and Patterson, 1980; Doupe et al., 1980).

\section{Materials and Methods}

SIF cell culture. Neonatal (1 to 3-day-old) rats (CD strain, Charles River Breeding Laboratories, Wilmington, MA) were killed by a blow to the head and the SCG were removed, placed in L15-Air plating medium (Mains and Patterson, 1973), cleaned of surrounding tissue and the collagenous ganglionic sheath, and mechanically dissociated with forceps. After allowing undissociated fragments to settle at room temperature in a conical centrifuge tube for 5 min, the supernatant containing the dissociated cells was set aside. The ganglionic pellet was passed through a 22 gauge needle three times to dissociate it further; more plating medium was then added and the fragments were allowod to settle for 5 to $10 \mathrm{~min}$. The supernatant from this dissociation was added to the first, and the cells were centrifuged at $800 \times$ $g$ for $5 \mathrm{~min}$. The pellet was resuspended in a small volume of growth medium and plated into culture dist ies at a density corresponding to approximately 5 to 6 ganglia/dish. When growth in $5 \mu \mathrm{M}$ dexamethasone (Sigma Chemical Co., St. Louis, MO), each dish had 200 to 300 cells after 2 to 3 weeks.

All other methods in this paper are as described in the preceding paper (Doupe et al., 1985).

\section{Results}

SIF cell cultures. The known effects of glucocorticoids on developing SIF cells (Eranko et al., 1972a) and on rat adrenal chromaffin cells (see Doupe et al., 1985) suggested that these hormones might be useful in attempting to establish dissociated cell cultures of SIF cells. Cells mechanically dissociated from the SCG of newborn rats were therefore plated into medium containing $5 \mu \mathrm{M}$ dexamethasone, a synthetic glucocorticoid. The medium contained no NGF, and nonneuronal cells were eliminated by treatment with antimitotic agents. In this situation cultures of small round or polygonal cells developed in the virtual absence of neurons and non-neuronal cells. The same results were obtained when $5 \mu \mathrm{M}$ hydrocortisone succinate or corticosterone were substituted for dexamethasone. Without the addition of corticosteroid or in the presence of $5 \mu \mathrm{M}$ progesterone, none of these small cells wcre cver obscrved at 3 wocks in vitro. The same cell suspension plated into NGF-containing medium without glucocorticoid gave rise to pure cultures of sympathetic neurons.

The small cells in cultures grown for 3 weeks in $5 \mu \mathrm{M}$ glucocorticoid were characterized in a variety of ways. Their appearance in the phase microscope was similar to that of adrenal chromaffin cells: their cell bodies were small ( 10 to $20 \mu \mathrm{m}$ ), usually round and phasebright, although occasionally more fusiform and flattened, and contained a small nucleus and nucleolus (Fig. 1a). Three to $18 \%$ of the cells had neurites, which varied in length (Fig. 1C). All of the cells had intense formaldehyde- or glyoxylic acid-induced CA fluorescence (Fig. 1, $b$ and $d$ ). When examined with the electron microscope, these cells had little rough endoplasmic reticulum but numerous free polyribosomes and Golgi bodies. Many cells had chromatin condensed along the nuclear envelope. Most strikingly, their cell somas and, when present, their neurites, contained numerous large CA storage granules, occasionally interspersed with clusters of small 50-nm vesicles (Fig. 2, a and b). In cultures grown in the presence of $5 \mu \mathrm{M}$ dexamethasone, the majority of cells had granular vesicles with an average diameter of $137 \pm 7 \mathrm{~nm}$ (SEM), which is similar to the diameter of adrenal chromaffin granules of type SIF ॥ cells (Table I). Cells with an average vesicle diameter of $99 \pm 1 \mathrm{~nm}$, as in type I SIF cells, were also observed, however (Fig. 2b). Sometimes vesicles were clustered at the membrane, at areas resembling release sites (Fig. $2 C$ ). 

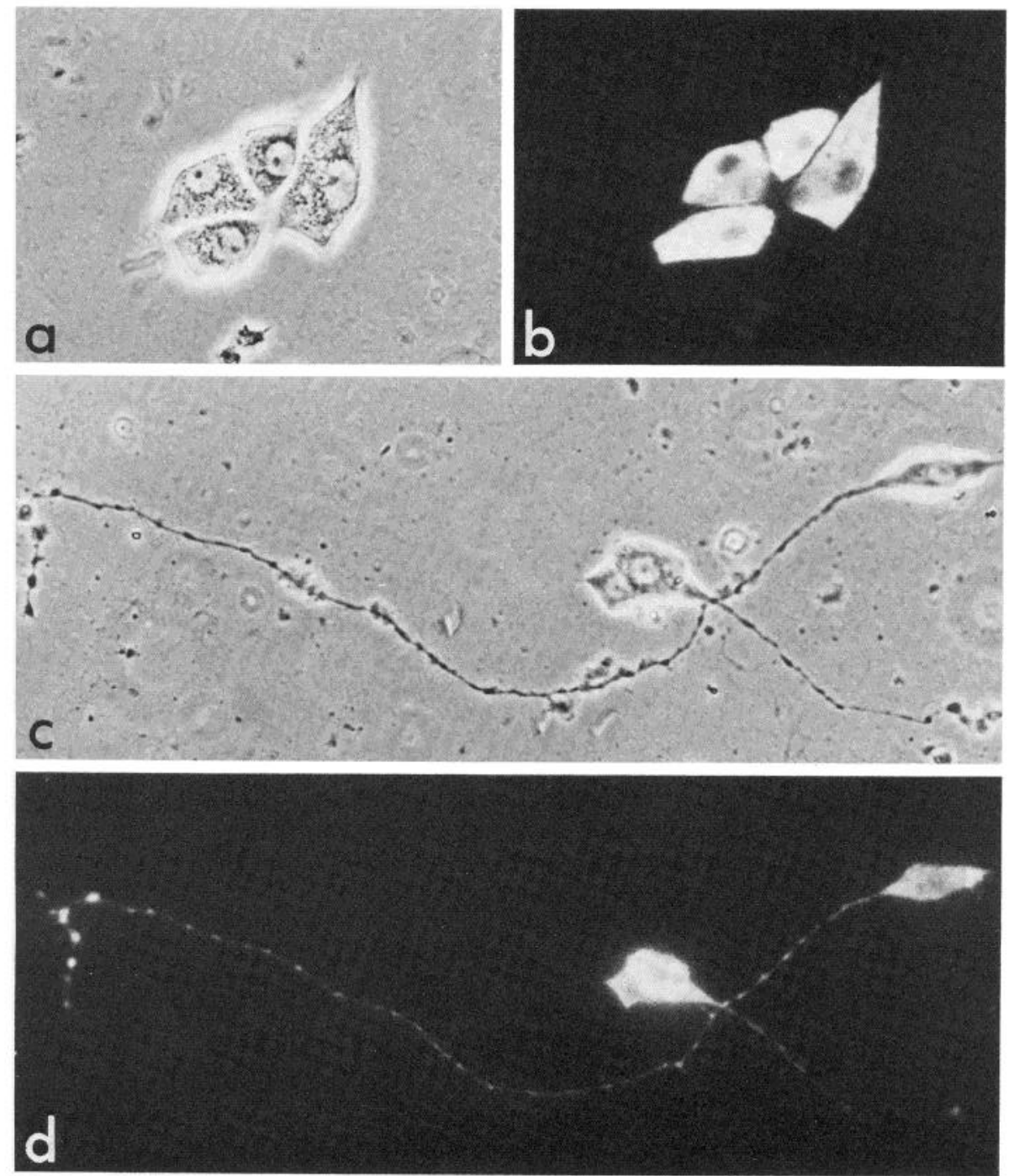

Figure 1. SIF cells cultured from newborn rat SCG. The phase microscopic appearance and corresponding intense glyoxylic acid-induced CA fluorescence of a cluster of SIF cells are shown in a and $b$. SIF cells with neurites in the phase microscope and their corresponding intense CA fluorescence are illustrated in $c$ and $d$. Magnification $x$ 420.
Synthesis and storage of CA were measured by incubating the cultures for $48 \mathrm{hr}$ with $\left[{ }^{14} \mathrm{C}\right]$ tyrosine. The labeled products were extracted in $0.17 \mathrm{M}$ acetic acid, separated by high pressure liquid chromatography and counted. Cultures grown in $5 \mu \mathrm{M}$ glucocorticoid synthesized and stored $4.9 \pm 0.9 \mathrm{fmol}$ of CA/cell, an amount similar to that stored by cultured adrenal chromaffin cells (Table I; Doupe et al., 1985). The products included all three neurotransmitters, norepinephrine, epinephrine, and dopamine, and the ratio of epinephrine to norepinephrine was $3.8 \pm 0.3$. Dopamine represented $18.8 \pm 1.1 \%$ and norepinephrine represented $16.2 \pm 0.9 \%$ of the CA synthesized and stored. Immunohistochemical studies with antibodies to the CA-synthetic enzyme allowed analysis of the probable transmitter phenotype of individual cells. There were $86.5 \pm 2.0 \%$ of the cells containing immunohistochemically detectable phenylethanolamine $\mathrm{N}$-methyltransferase (PNMT) and $92.9 \pm 1.5 \%$ containing dopamine $\beta$-hydroxylase (DBH)-immunoreactive material (Table I, Fig. 3). The majority of cells therefore appeared to store epinephrine, but these results also suggested that there were as many as three different cell populations in the cultures; that is, cells storing predominantly norepinephrine (which displayed DBH but no PNMT immunoreactivity) and cells storing only dopamine (without DBH or PNMT immunoreactivity), in addition to the PNMT-immunoreactive cells.

Thus, when cells from neonatal rat SCG were grown in dissociated cell culture with $5 \mu \mathrm{m}$ glucocorticoid, pure cultures of cells with the characteristic morphology, CA fluorescence, ultrastructure, and biochemical properties expected of mature type I and type II SIF cells were obtained.
Development of SIF cells in culture. What is the origin of the well differentiated SIF cells seen after 3 weeks in vitro? One possibility is that these cells are pre-existing, fully differentiated SIF cells which were dissociated from the neonatal SCG and survived under these culture conditions. Alternatively, the SIF cells might have differentiated in vitro under the influence of glucocorticoid. To distinguish these possibilities, cell cultures were analyzed at various times after plating. Most cells did not display the intense fluorescence and characteristic ultrastructure of SIF cells at early times in vitro. Instead, these properties developed slowly over the first 7 to 10 days in culture. The development of CA fluorescence is shown in Figure 4. The number of pre-existing, differentiated SIF cells present very early after plating was variable, but the total number of fluorescent SIF cells always increased 3- to 10 -fold in the first week. Most of the differentiated principal neurons died in the first 1 to 4 days after plating. There were few PNMT-immunoreactive cells in the cultures at $24 \mathrm{hr}$ after plating, although sister cultures had several hundred PNMT-staining cells after 3 weeks in vitro. In young cultures examined with the electron microscope, the cells lacked the defining characteristics of mature SIF cells, did not resemble neurons, and appeared immature. Figure 5 shows a representative cell from a 4 day-old culture in $5 \mu \mathrm{M}$ dexamethasone: it has relatively little cytoplasm and the cell body lacks CA storage granules. A few cells containing scattered chromaffin vesicles of type I size were also observed. After 7 to 10 days in culture, the cell number was stable, more than $95 \%$ of the cells displayed intense CA fluorescence, and virtually all of the cells examined had characteristic granular vesicles. 

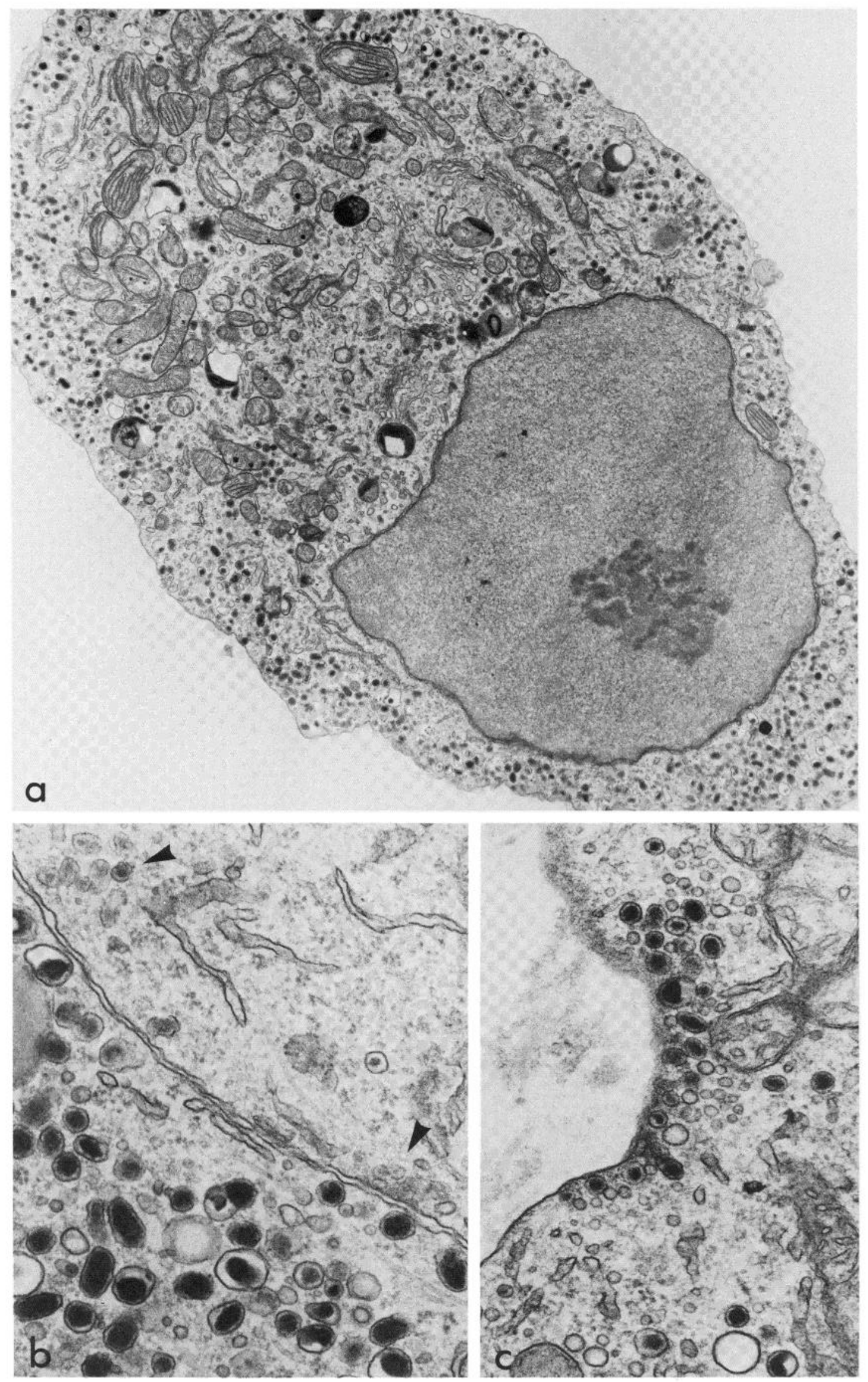

Figure 2. Ultrastructure of cultured SIF cells. a, Cell bodies have very little rough endoplasmic reticulum, abundant Golgi and free polyribosomes, and numerous large catecholamine storage vesicles. Magnification $\times 11,800$. SIF cell CA granules are shown at higher magnification in $b$ and $c$. Note that in $b$ the cell to the lower left is a type II cell, with granules 150 to $300 \mathrm{~nm}$ in diameter, while the cell on the upper right is a type I cell (vesicles 80 to $150 \mathrm{~nm}$ in diameter), as is the cell in c. Arrowheads point to small vesicles. Occasional SIF cells show accumulations of small vesicles focused at areas resembling release sites $(c)$. Magnification $\times 43,700$. 
TABLE I

Differentiated characteristics of SIF cells grown in various concentrations of glucocorticoid hormone in the presence or absence of CM

\begin{tabular}{|c|c|c|c|c|c|}
\hline \multirow{2}{*}{ Glucocorticoid } & \multirow{2}{*}{$\begin{array}{l}\text { Percentage } \\
\text { PNMT+ }\end{array}$} & \multirow{2}{*}{$\begin{array}{c}\text { Percentage } \\
\mathrm{DBH}+\end{array}$} & \multicolumn{2}{|c|}{ CA Synthesis } & \multirow{2}{*}{$\begin{array}{c}\text { Vesicle } \\
\text { Diameters } \\
(\mathrm{nm})\end{array}$} \\
\hline & & & $\mathrm{fmol} / \mathrm{cell}$ & $\mathrm{E} / \mathrm{NE}^{a}$ & \\
\hline $5 \mu \mathrm{M} \operatorname{dex}^{b}$ & $\begin{array}{c}86.5 \pm 2.0 \\
(n=6)^{c}\end{array}$ & $\begin{array}{c}92.9 \pm 1.5 \\
(n=4)\end{array}$ & $\begin{array}{c}4.9 \pm 0.9 \\
(n=8)\end{array}$ & $\begin{array}{c}3.8 \pm 0.3 \\
(n=9)\end{array}$ & $\begin{array}{c}\text { I: } 137 \pm 7 \\
(n=6) \\
\text { II: } \quad 99 \pm 1 \\
(n=3)\end{array}$ \\
\hline $10^{-8} \mathrm{M} \operatorname{dex}$ & $\begin{array}{c}66.8 \pm 3.9 \\
(n=5)\end{array}$ & $\begin{array}{c}81.7 \pm 1.7 \\
(n=2)\end{array}$ & $\mathrm{ND}^{d}$ & ND & $\begin{array}{c}\text { I: } \quad 82 \pm 7 \\
(n=2)\end{array}$ \\
\hline $5 \mu \mathrm{M} d e x+C M$ & $\begin{array}{c}69.0 \pm 6.9 \\
(n=4)\end{array}$ & ND & ND & ND & $\begin{array}{c}\text { I: } \quad 65 \pm 2 \\
(n=6)\end{array}$ \\
\hline $10^{-8} \mathrm{M} \mathrm{dex}+\mathrm{CM}$ & $\begin{array}{c}20.4 \pm 5.2 \\
(n=5)\end{array}$ & ND & ND & ND & $\begin{array}{c}\text { I: } \quad 60 \pm 3 \\
(n=4)\end{array}$ \\
\hline
\end{tabular}

${ }^{a} \mathrm{E}$, epinephrine; $\mathrm{NE}$, norepinephrine.

${ }^{b}$ dex, dexamethasone.

${ }^{c} n$, number of cultures tested or cells in which vesicles were measured.

${ }^{\sigma} \mathrm{ND}$, not determined.

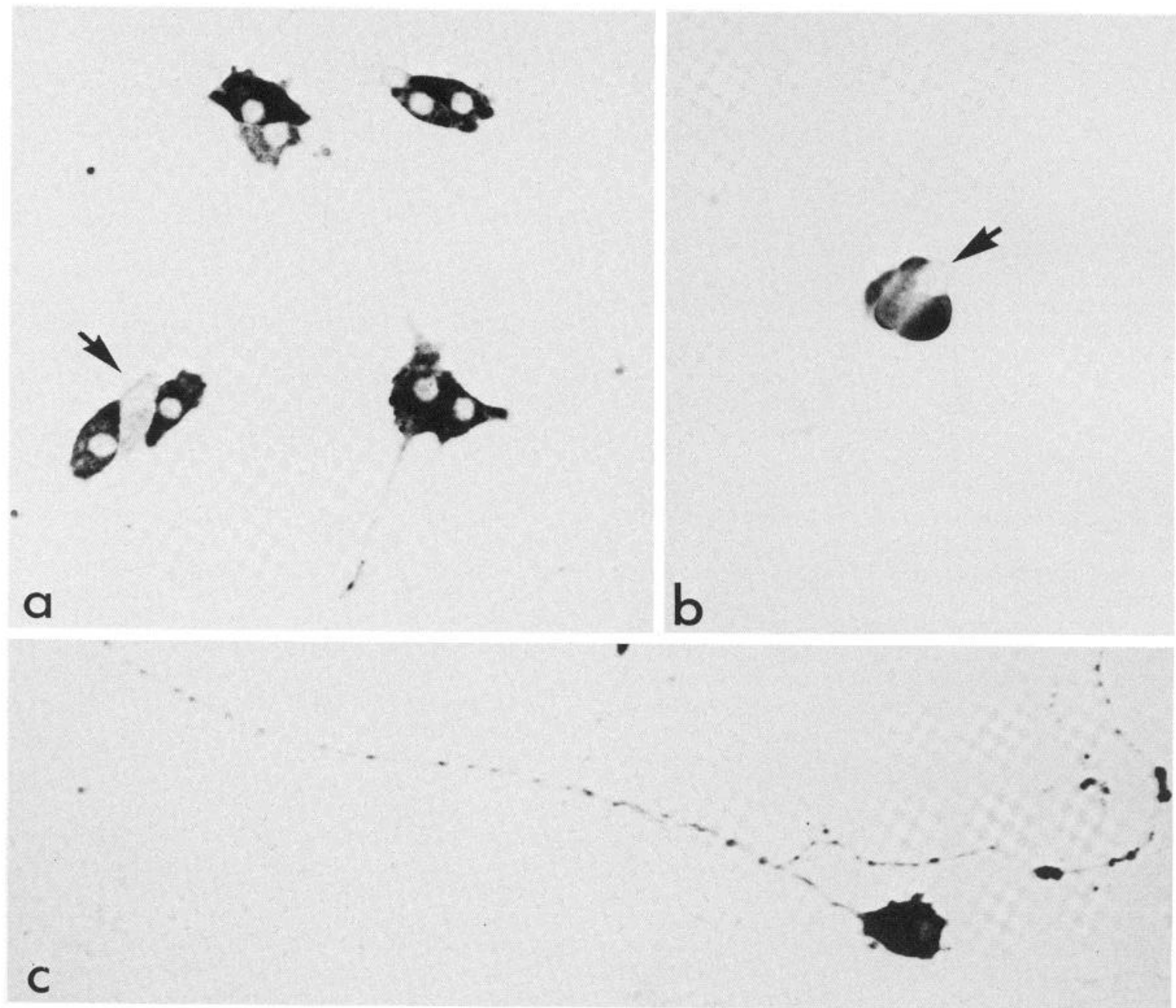

Figure 3. CA synthetic enzymes in SIF cells in vitro. Cells display immunoreactivity to DBH (a) and PNMT (b). Arrows point to cells without detectable immunoreactivity. $c$ shows a DBH-immunoreactive cell with a neurite. Magnification $\times 420$.

Therefore, most SIF cells appeared to be differentiating in vitro. It was surprising that so few of the pre-existing SIF cells in the ganglion were found in these cultures. Many SIF cells were clearly not well dissociated from the blood vessels in this mechanical dissociation procedure, since numerous intensely CA-histofluorescent cells were observed in the remnants which settled out of the cell suspension and were not used for plating (Fig. 6).
Role of corticosteroid concentration. Most SIF cells in the rat SCG in vivo are dopaminergic and have type I-sized vesicles (Bjorklund et al., 1970; Fuxe et al., 1971; Lever et al., 1976; Rybarczyck et al., 1976). In contrast, more than $80 \%$ of the SIF cells grown in $5 \mu \mathrm{M}$ glucocorticoid were PNMT immunoreactive, and most of the cells had large, type II granular vesicles. The cultured cells therefore resembled chromaffin cells of the rat adrenal medulla (see Doupe et 


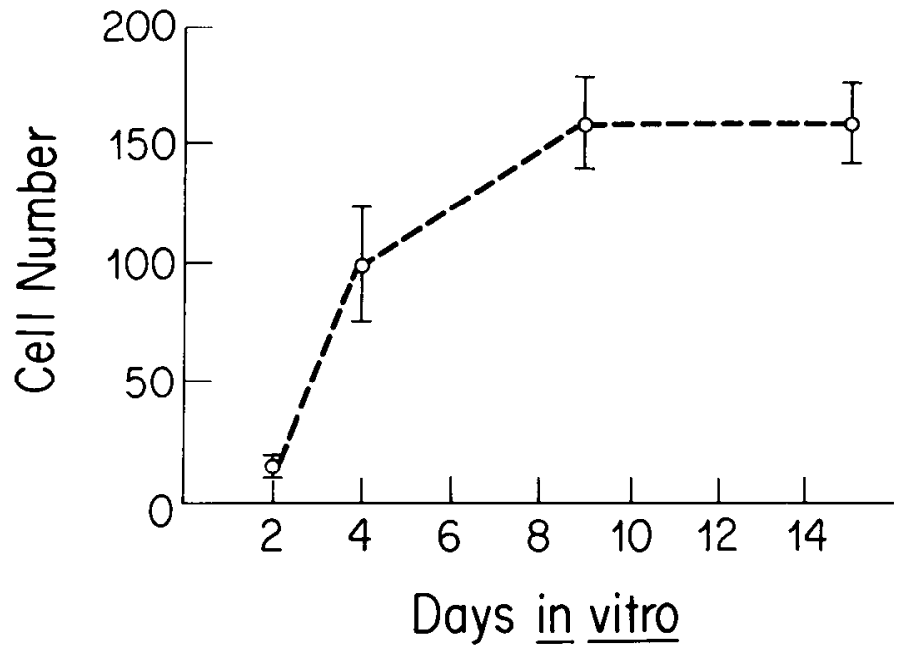

Figure 4. Development of intense CA fluorescence in cultures grown with $5 \mu \mathrm{M}$ dexamethasone. All of the intensely fluorescent cells in each of three sister cultures were counted in the fluorcscence microscope at the indicated days after plating. Numbers are expressed as mean \pm SEM. In the experiment shown, SIF cells were on a collagen substrate and the Falck-Hillarp reaction was used to detect CA. Sirmilar results were seerl wilh the givoxylic acid reaction. When cells were plated on a more adhesive substrate (such as bovine corneal ECM), the initial number of fluorescent cells detected at days 1 and 2 was always higher but nonetheless increased 3- to 10-told during the first week in culture.

al., 1985) more than they did the majority of SCG SIF cells in vivo. In the normal environment of medullary chromaffin cells, glucocorticoid levels are in the micromolar range, which is several orders of magnitude higher than in the general circulation. Moreover, glucocorticoid is known to induce PNMT and epinephrinc synthosis in developing SIF cells of the SCG (Ciaranello et al., 1973; Bohn et al., 1982). These observations raised the possibility that the level of glucocorticoid hormone might play a role in determining the transmitter of the cultured SIF cells and the proportion of type I and type II cells in the cultures. To tost this, cclls dissociated from newborn SCG were grown in the presence of $10^{-8} \mathrm{M}$ dexamethasone instead of $5 \times 10^{-6} \mathrm{M}$.

All the cells present in the cultures after three weeks growth in $10^{-8} \mathrm{M}$ steroid were differentiated SIF cells, displaying intense CA fluorcscence and characteristic SIF cell ultrastructure (Fig. 7, a and c). The most striking effect of the lower hormone concentration was on SIF cell number. The relationship of SIF cell number to hormone concentration is shown in Figure 8. Essentially no SIF cells were observed until hormone concentrations were greater than $10^{-9} \mathrm{M}$, and the number of cells at $10^{-8} \mathrm{M}$ was routinely 3 to 10 times lower than at saturating concentrations $\left(10^{-6} \mathrm{M}\right)$. In many experiments there was a decrease in SIF cell number at $10^{-4} \mathrm{M}$ dexamethasone or above. As was true tor adrenal chromaffin cells (Doupe et al., 1985), even differentiated SIF cells depended on glucocorticoid for continued survival and maintenance of differentiation in culture. When corticosteroid was withdrawn from SIF cell cultures that had grown for 2 weeks in $5 \mu \mathrm{M}$ dexamethasone, only $55.1 \pm 0.4 \%(n=$ 2) of the original number of SIF cells were alive after a further 2 weeks, compared to $85.6 \pm 5.2 \%(n=2)$ of SIF cells maintained in high glucocorticoid.

A second effect of growth in lower hormone concentration was that a higher percentage of cells had neurites. In general, the proportion of cells bearing neurites was influenced by the culture substrate: cells grown on collagen had fewer neurites than cells grown on a more adhesive substrate, collagen coated with bovine corneal endothelial cell extracellular matrix (ECM) (Fujii et al., 1982; Doupe et al., 1985). Nonetheless, the difference between the two hormone concentrations in the percentage of neurite-bearing cells was seen on all culture substrates. On bovine ECM, $10.6 \pm 0.4 \%$
( $n=4$ ) of the cells in $5 \mu \mathrm{M}$ dexamethasone had long (>5 cell body diameters) neurites, compared to $24.8 \pm 1.6 \%(n=4)$ of cells in $10^{-8} \mathrm{M}$ hormone. Cells with neurites were frequently observed to be associated with the occasional fibroblast-like cells remaining in the cultures. These non-neuronal cells may represent a source of NGFlike activity and promote neurite outgrowth, but they were present in similar amounts in the two hormone concentrations and thus did not explain the observed hormone-dependent difference in neurite outgrowth.

A third effect of low hormone concentration was on the relative numbers of SIF cell types. The proportion of cells with type I SIF cell morphology was higher in $10^{-8} \mathrm{M}$ corticosteroid than in $5 \mu \mathrm{M}$, although some type II cells were clearly present. Typical type I and II SIF cells grown in $10^{-8} \mathrm{M}$ dexamcthasone are shown in Figurc 7 , $a$ and $c$. Biochemical analysis of the transmitter synthesized by SIF cells grown in $10^{-8} \mathrm{M}$ hormone was more difficult because of the low cell number. It was clear, however, that some epinephrine was still synthesized and stored in these cultures (data not shown), although the epinephrine/norepinephrine ratio was lower than in cells grown in $5 \mu \mathrm{M}$ dexamethasone (ranging from 0.2 to 2.4 in $10^{-8} \mathrm{M}$ dexamethasone). SIF cells in $10^{-8} \mathrm{M}$ glucocorticoid also had PNMT and DBH immunoreactivity. The percentage of PNMT-immunoreactive cells was $66.8 \pm 3.9 \%$, compared to greater than $80 \%$ for cells in $5 \mu \mathrm{M}$ hormone (Table I). The percentage of $\mathrm{DBH}$-immunoreactive cells was $81.7 \pm 1.7$ (Table 1 ), also lower than in micromolar glucocorticoid. Thus, cultures grown at lower hormone concentrations contained more cells with type I ultrastructure and more cells without PNMT or DBH immunoreactivity, although there were also type II and PNMT-immunoreactive SIF cells present.

Effects of conditioned medium. Growth in $10^{-8} \mathrm{M}$ hormone did not yield a population composed exclusively of dopaminergic, type I SIF cells such as those which normally predominate in the adult rat SCG. Other potential environmental factors include the non-neuronal cells in the ganglion, such as satellite cells, fibroblasts, or cells of the blood vessels around which SIF cells are usually clustered. To assess the role of non-neuronal cell factors, serum-free CM was added to the hormone-containing medium. To block the small amount of NGF-like activity that is known to be produced by these non-neuronal cells in culture (Chun and Patterson, 1977), an antiserum to NGF was included with the CM. Essentially all of the celis observed after 3 weeks of culture in this medium were small and showed intense CA fluorescence (data nol showni). Cell survival was not different in the presence of $\mathrm{CM}+$ steroid compared to steroid alone, and no SIF cells were observed in cultures grown with $\mathrm{CM}$ but in the absence of glucocorticoid. The presence of $\mathrm{CM}$ in the hormone-containing medium resulted in a much higher percentage of cells with long neurites. A total of $68.8 \pm 0.5 \%(n=2)$ of the cells grown in the equivalent of $100 \% \mathrm{CM}$ and $5 \mu \mathrm{M}$ glucocorticoid had processes, whereas $93.4 \pm 3.2 \%(n=4)$ of cells grown in $10^{-8}$ $\mathrm{M}$ glucocorticoid and $\mathrm{CM}$ had neutites. Ultrastructural studies of these cells revealed that virtually all of the cells had type I morphology, that is, granular vesicles of intermediate diameter (70 to 120 $\mathrm{nm}$ ) and occasional clusters of 50-nm vesicles (Table I, Fig. 7, $b$ and d). This result was observed both in $5 \mu \mathrm{M}$ and $10^{-8} \mathrm{M}$ glucocorticoid. Representative distributions of vesicle diameters (measured in the cell bodies) are shown in Figure 9 . The mean diameter of granules in $5 \mu \mathrm{M}$ glucocorticoid plus $\mathrm{CM}$ was $65.1 \pm 2.4 \mathrm{~nm}$ and in $10^{-8} \mathrm{M}$ dexamethasone plus CM it was $59.8 \pm 2.7 \mathrm{~nm}$ (Table I). This mean is smaller than granules in type I SIF cells in glucocorticoid alone. In some cases the smaller mean diameter reflected a large population of $50-\mathrm{nm}$ vesicles in addition to type I SIF vesicles (Figs. $7 d$ and $9 c$ ). In other cases there appeared to be one population of vesicles with a smaller mean granule diameter than in type I SIF cells in hormone alone (Figs. $8 b$ and $9 c$ ). This diameter is similar to that observed by some authors for rat carotid body SIF cells (Hellstrom, 1975).

Cells grown in hormone and CM were also analyzed for the presence of DBH and PNMT immunoreactivity (Table I). In contrast to cultures grown in $5 \mu \mathrm{M}$ hormone alone, only $69.0 \pm 6.9 \%$ of cells 


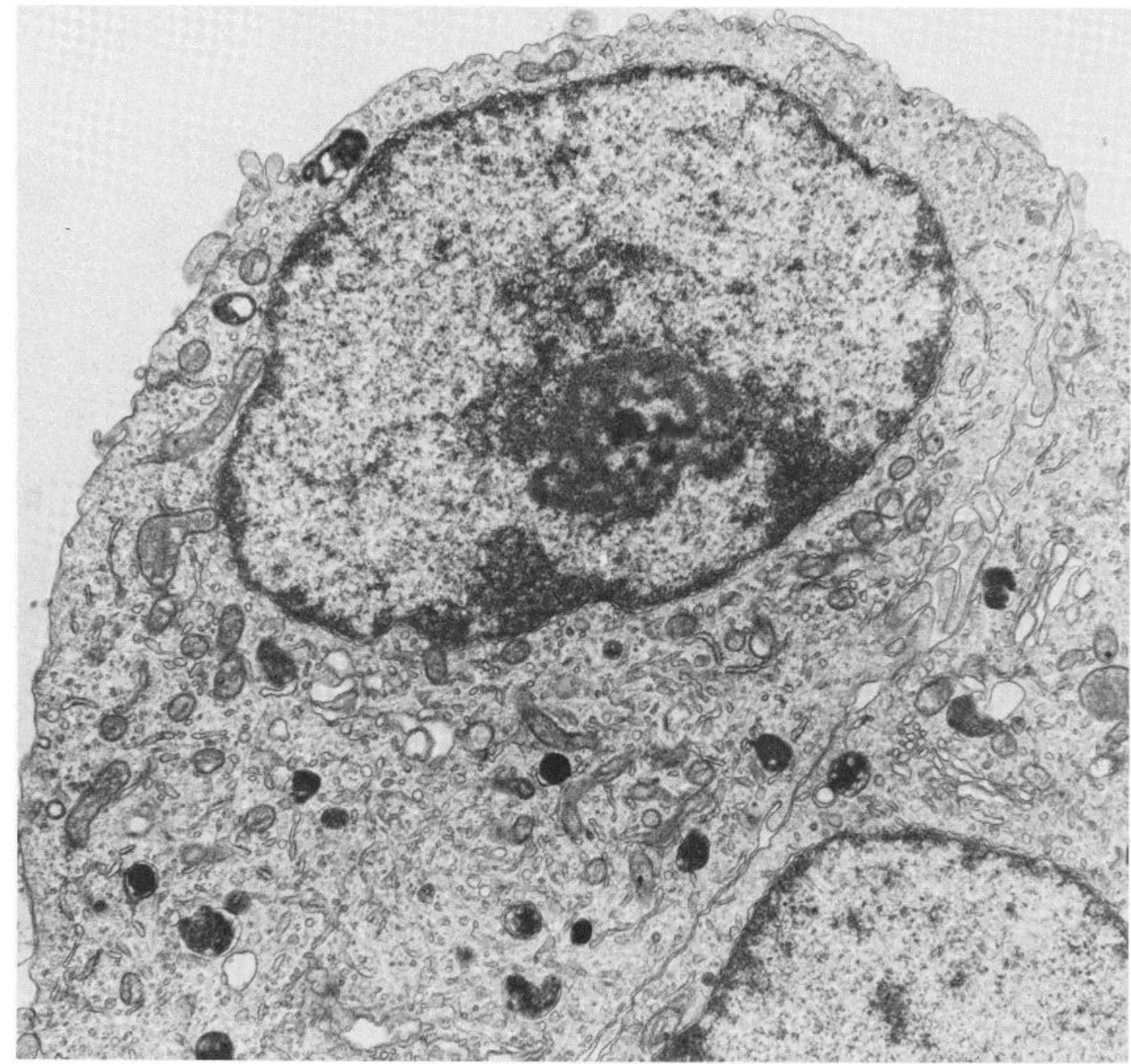

Figure 5. Development of SIF cells in culture. Representative cells from an SIF cell culture 3.5 days after plating. Note that both cell bodies are virtually free of CA granules. The large electron-dense organelles are lysosomes. Magnification $\times 11,800$.

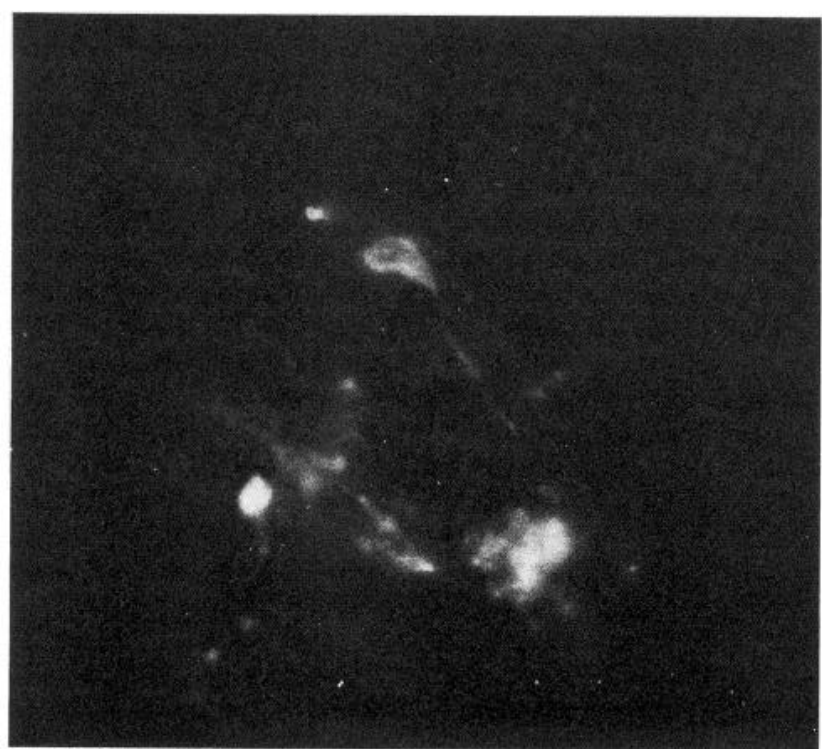

Figure 6. Glyoxylic acid-induced CA-fluorescent cells are apparent in the ganglionic pellet not used for plating. These SIF cells retain intense CA fluorescence during dissociation. Magnification $\times 350$. in $5 \mu \mathrm{M}$ glucocorticoid plus CM were immunoreactive for PNMT. PNMT immunoreactivity was variable in cultures grown in $10^{-8} \mathrm{M}$ dexamethasone plus $\mathrm{CM}$, but the percentage of positive cells was very low, ranging from 0 to $27.3 \%$ (mean $20.4 \pm 5.2 \%$ ). In preliminary experiments, $\mathrm{DBH}$ immunoreactivity was only slightly reduced in cultures grown in $5 \mu \mathrm{M}$ hormone plus CM $(87 \%$ versus $93 \%$ in $5 \mu \mathrm{M}$ hormone alone). SIF cells developing in the presence of non-neuronal cell $\mathrm{CM}$ as well as glucocorticoid were more likely to have neurites and displayed a lower percentage of PNMT immunoreactivity; virtually all contained granular vesicles of small or intermediate diameters and, thus, were more like type I SIF cells in vivo.

Effects of NGF. Adrenal chromaffin cells are NGF-responsive (Olson, 1970; Unsicker et al., 1978; Aloe and Levi-Montalcini, 1979; Tischler et al., 1980) and can become indistinguishable from sympathetic neurons with long-term culture in NGF (see Doupe et al., 1985). To examine the NGF response of SIF cells, cells from the newborn rat SCG were grown in $5 \mu \mathrm{M}$ dexamethasone for 10 to 12 days, by which time all of the cells in the culture were differentiated SIF cells. When the glucocorticoid was withdrawn and NGF added, 75 to $85 \%$ of the cells responded with process outgrowth. The majority of these cells proceeded to lose their intense CA fluorescence (see Fig. 11) and to assume a neuronal morphology (Figs. 10 and 11; Fig. 10 shows the conversion of identified SIF cells into neurons, followed over 2 weeks in culture).

SIF cell-derived neurons also displayed neuronal ultrastructure: their cell bodies were enlarged and contained abundant rough 

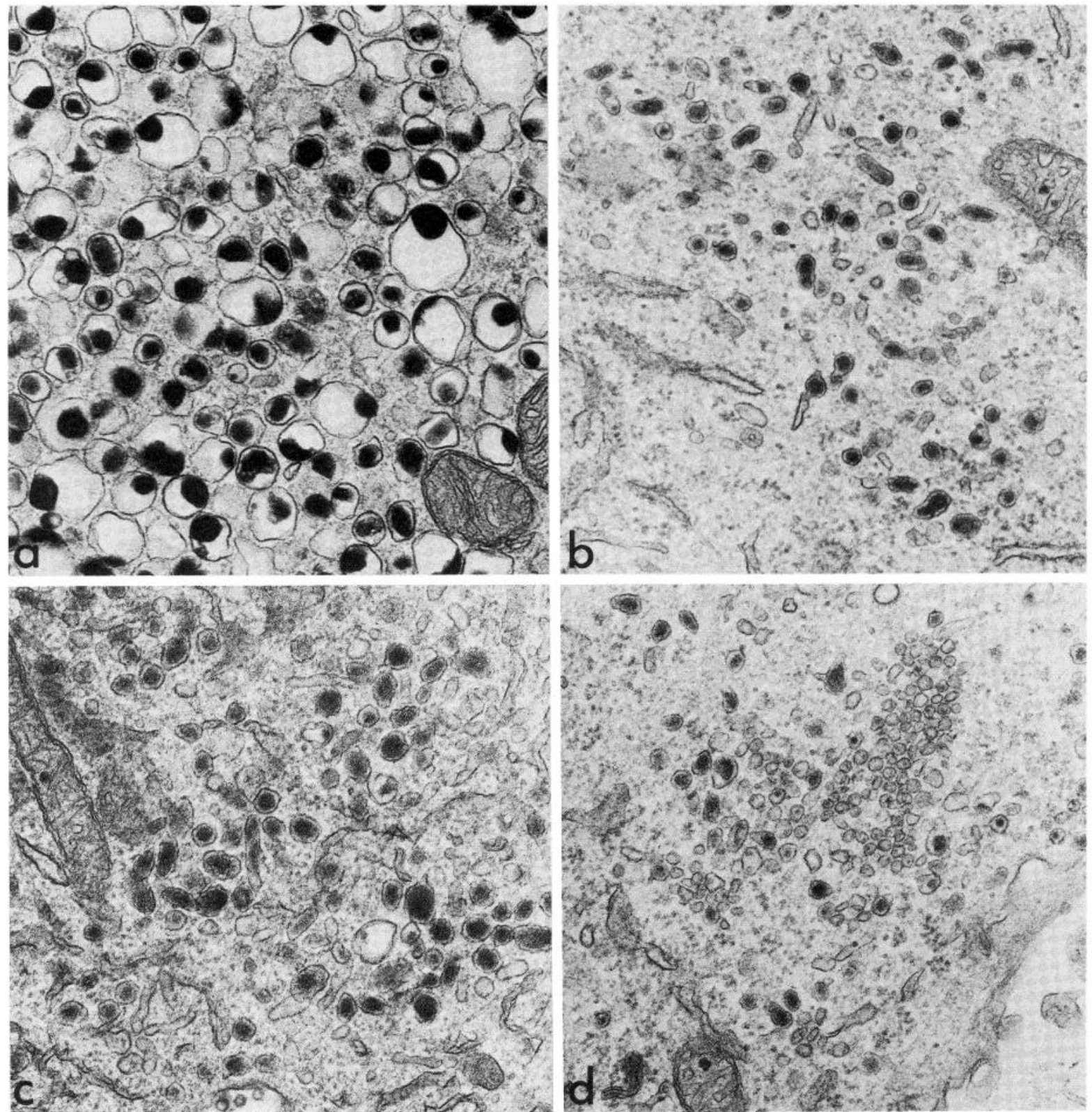

Figure 7. Cultured SIF cells in low $\left(10^{-8} \mathrm{M}\right)$ hormone concentration or in the presence of $\mathrm{CM}$ as well as hormone. The ultrastructure of a type $\|$ cell in an SIF cell culture with $10^{-8} \mathrm{M}$ dexamethasone is shown in a and that of a type I SIF cell in the same culture is shown in $c$. Magnification $\times 43,700$. $b$ and $a$ show granular vesicles from two different cells in $5 \mu \mathrm{m}$ hormone plus CM. Magnification $\times 43,700$.

endoplasmic reticulum and Golgi apparatus, and were no longer filled with CA granular vesicles. Their long axons had varicosities containing small synaptic vesicles, as well as occasional larger, neuronal dense-cored vesicles. These neurons formed morphologically specialized synapses with each other within 2 weeks of NGF addition (see Fig. 13). The ultrastructure of the identified SIF cellderived neurons in Figure 10 is shown in Figures 12 and 13.

As is true of adrenal chromaffin cells (Lietzke and Unsicker, 1983; Doupe et al., 1985), SIF cells acquired a number of neuronal markers in response to NGF. At days 10 to 12 in vitro, only $25.5 \pm 9.6 \%$ ( $n$ $=5$ ) of SIF cells grown in $5 \times 10^{-6} \mathrm{M}$ steroid showed labeling with tetanus toxin and anti-tetanus toxoid. In dexamethasone-containing cultures, this percentage increased over the next 3 weeks in culture to $56.4 \% \pm 4.5 \%$ (Table II); the tetanus toxin-labeled population included all of the SIF cells with short processes and $30.8 \%(n=3)$ of SIF cells without processes. After 3 weeks with NGF, however, $89.6 \pm 5.2 \%$ of the cells in the cultures bound tetanus toxin on their cell bodies and their processes (Fig. 11C, Table II): this percentage included all of the cells with processes and a small number of SIF cells without processes.

The percentage of SIF cells that grew processes in response to NGF alone was $82.4 \pm 5.1$ (Table II). This neurite outgrowth response is therefore much more vigorous than that of cultured adrenal chromaffin cells. Only 10 to $40 \%$ of medullary chromaffin cells responded to NGF alone with neuronal conversion, whereas most other chromaffin cells died (Doupe et al., 1985). Inclusion of heart cell CM plus NGF increased the percentage of SIF cells which responded with process outgrowth to $96.9 \pm 0.8 \%$.

As with adrenal chromaffin cells, individual SIF cells varied in the amount of neuronal differentiation they had undergone in response to NGF. Similarly, increasing the length of time in culture with NGF increased the number of neurons present. After 2 weeks with NGF alone, 30 to $50 \%$ of the cells in the cultures still had intense CA fluorescence although more than $80 \%$ of the cells had neurites (see 


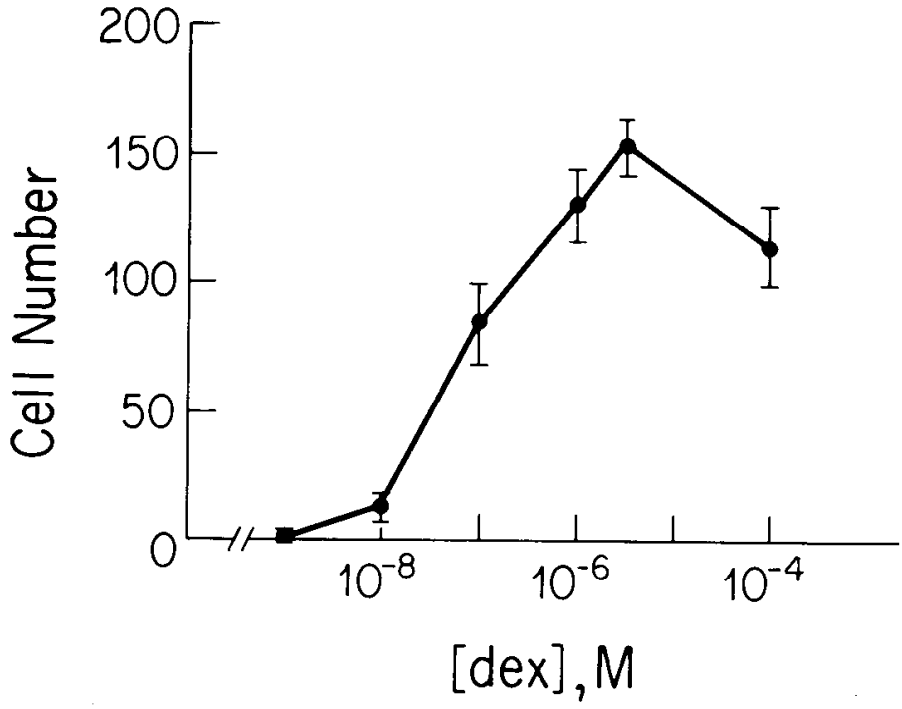

Figure 8. Effect of corticosteroid concentration on SIF cell number. Equal numbers of SCG cells were plated into different hormone concentrations, and after 3 weeks all of the cells with bright CA histofluorescence in each of three sister cultures were counted in the fluorescence microscope. Numbers are expressed as the mean \pm SEM.

Fig. 11 $a$ and $b$, Table II). After a longer time in NGF, the percentage of intensely fluorescent cells was much decreased. In the presence of $\mathrm{CM}$ the percentage of fiuorescent cells decreased more rapidly (to approximately $10 \%$ of the total after 2 weeks in NGF). Many of the fluorescent cells in the NGF-containing cultures were SIF cells which had not responded to NGF, but one-third to one-half of the intensely fluorescent cells appeared to be SIF cells in the process of becoming neurons (Fig. 11a). At the ultrastructural level cells were observed that had numerous granular vesicles of the type I size in their cell bodies. It is likely that these corresponded to the transitional cells seen with CA histofluorescence.

SIF cells were intermediate between neurons and chromaffin cells in their response to the presence of NGF plus corticosteroid. Corticosteroid greatly decreases the NGF-induced outgrowth of chromaffin cells and has no effect on neurite outgrowth of sympathetic neurons (see Unsicker et al., 1978; Doupe et al., 1985). In SIF cell cultures grown for 10 to 12 days in $5 \mu \mathrm{M}$ corticosteroid, and then switched to medium containing NGF as well as glucocorticoid, 53.5 $\pm 3.8 \%$ of the cells still grew processes (Table II). Similarly, $64.5 \pm$ $6.6 \%$ of the cells bound tetanus toxin when switched to medium containing both NGF and glucocorticoid. These cultures also contained a higher percentage of cells $(69.1 \pm 9.1 \%)$ with intense CA fluorescence (Table II). When the cultures were examined with the electron microscope, some cells appeared neuronal, but there were also SIF cells and neurite-bearing cells with type I CA vesicles similar to the incompletely transformed cells described above (Fig. 14a). The type I vesicles in these cells were frequently interspersed with small clusters of synaptic vesicles (Fig. 14b).

\section{Discussion}

In this study conditions were established for growing dissociated SIF cell cultures from the newborn rat SCG, and the dependence of these cells on glucocorticoid for survival and differentiation was demonstrated. The types of SIF cells that develop can be influenced by both the corticosteroid concentration and non-neuronal CM. The cultures can be induced to contain mostly epinephrine-storing, type II SIF cells, or primarily type I SIF cells with a phenotype intermediate between that of chromaffin cells and neurons, or a mixture of both. Finally, differentiated SIF cells can respond to withdrawal of corticosteroid and administration of NGF by converting into cells indistinguishable from mature sympathetic neurons.

In the presence of glucocorticoid and the absence of NGF, a pure

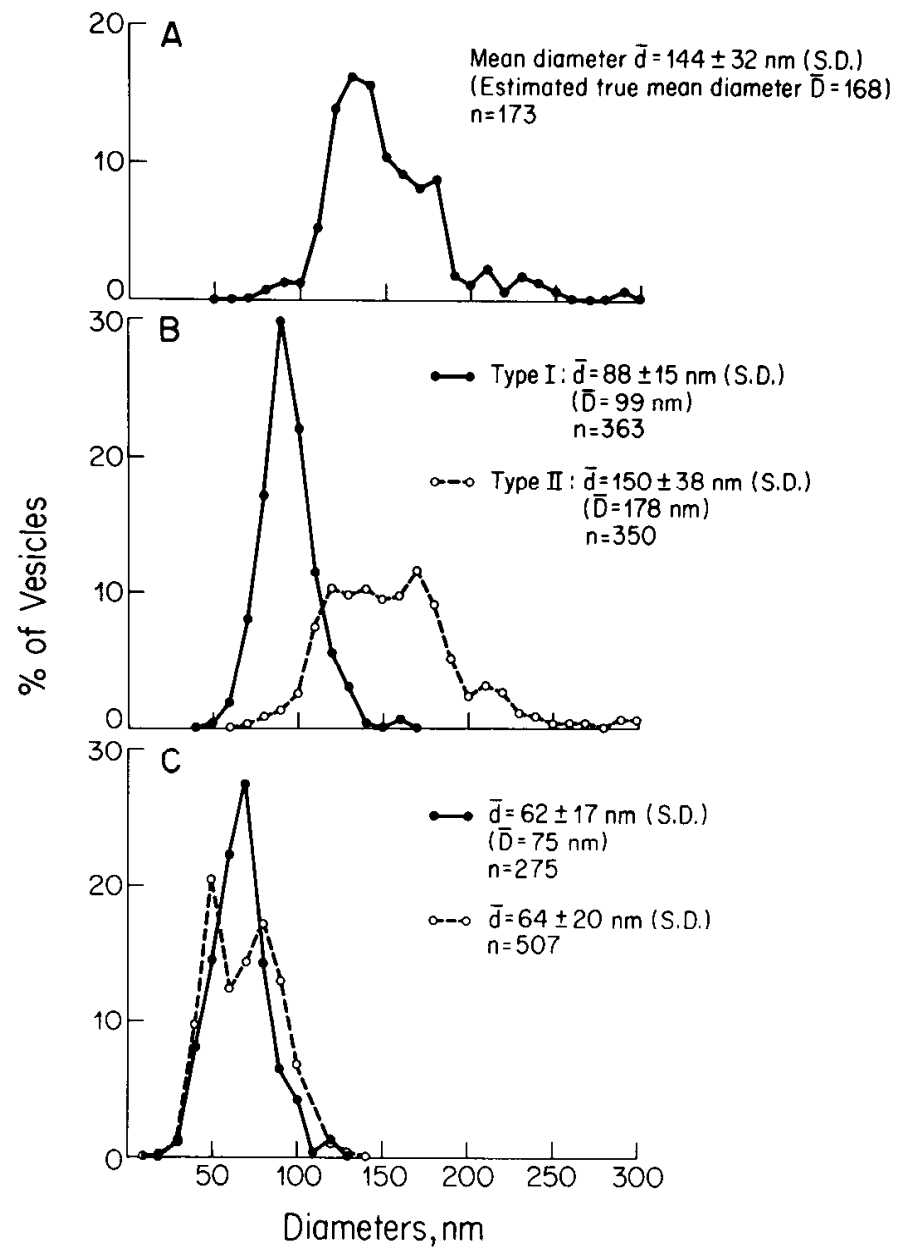

Figure 9. Distribution of vesicle diameters of SIF cells. A shows the vesicle diameters of a typical type II SIF cell in a culture with $5 \mu \mathrm{M}$ dexamethasone. In $B$ are depicted the vesicle diameters from a type $1(0)$ and a type $\|(O)$ cell from a culture grown with $10^{-8} \mathrm{M}$ glucocorticoid. The vesicle diameters from two type I cells from a culture grown in $5 \mu \mathrm{M}$ dexamethasone plus $C M$ are shown in $C$. The inset in each pane/ shows the mean profile diameter $\bar{d}$. the estimated true mean diameter $\bar{D}$, calculated as described under "Materials and Methods," and the number of vesicles measured per cell.

population of SIF cells could be grown from the neonatal rat SCG. The properties of the cultured SIF cells included (i) small cell body size and occasional prosence of short neurites, (ii) intense CA fiuorescence, (iii) synthesis and storage of CA, and (iv) characteristic ultrastructure as described for SIF cells in vivo (Siegrist et al., 1968; Matthews and Raisman, 1969; Williams and Palay, 1969; Taxi, 1979). SIF cells with the morphological appearance of type I and type I| cells were both seen in the cultures in $5 \mu \mathrm{M}$ dexamethasone, although type II cells predominated.

Most SIF cells in the adult rat SCG store dopamine and have type I granular vesicles (Williams and Palay, 1969; Lu et al., 1976). However, the cultures grown in $5 \mu \mathrm{M}$ glucocorticoid, synthesized large amounts of epinephrine and most of the SIF cells contained PNMT immunoreactivity and type Il granules. Dexamethasone $(5 \mu \mathrm{M})$ is similar to the concentration of glucocorticoid in the adrenal medulla in vivo, which receives the corticosteroid-rich venous outflow of the surrounding adrenal cortex (Jones et al., 1977). In that environment, the majority of chromaffin cells synthesize epinephrine and norepinephrine, and store the amines in large type II granules (Coupland, 1965a, b; Elfvin, 1967). Most of the SIF cells which developed in 5 $\mu \mathrm{M}$ hormone therefore resembled adrenal chromaffin cells. In SCG cultures grown in lower $\left(10^{-8} \mathrm{M}\right)$ hormone concentrations, the type I phenotype was more prominent, with a greater proportion of neuritebearing cells, a smaller percentage of PNMT immunoreactivity, and 

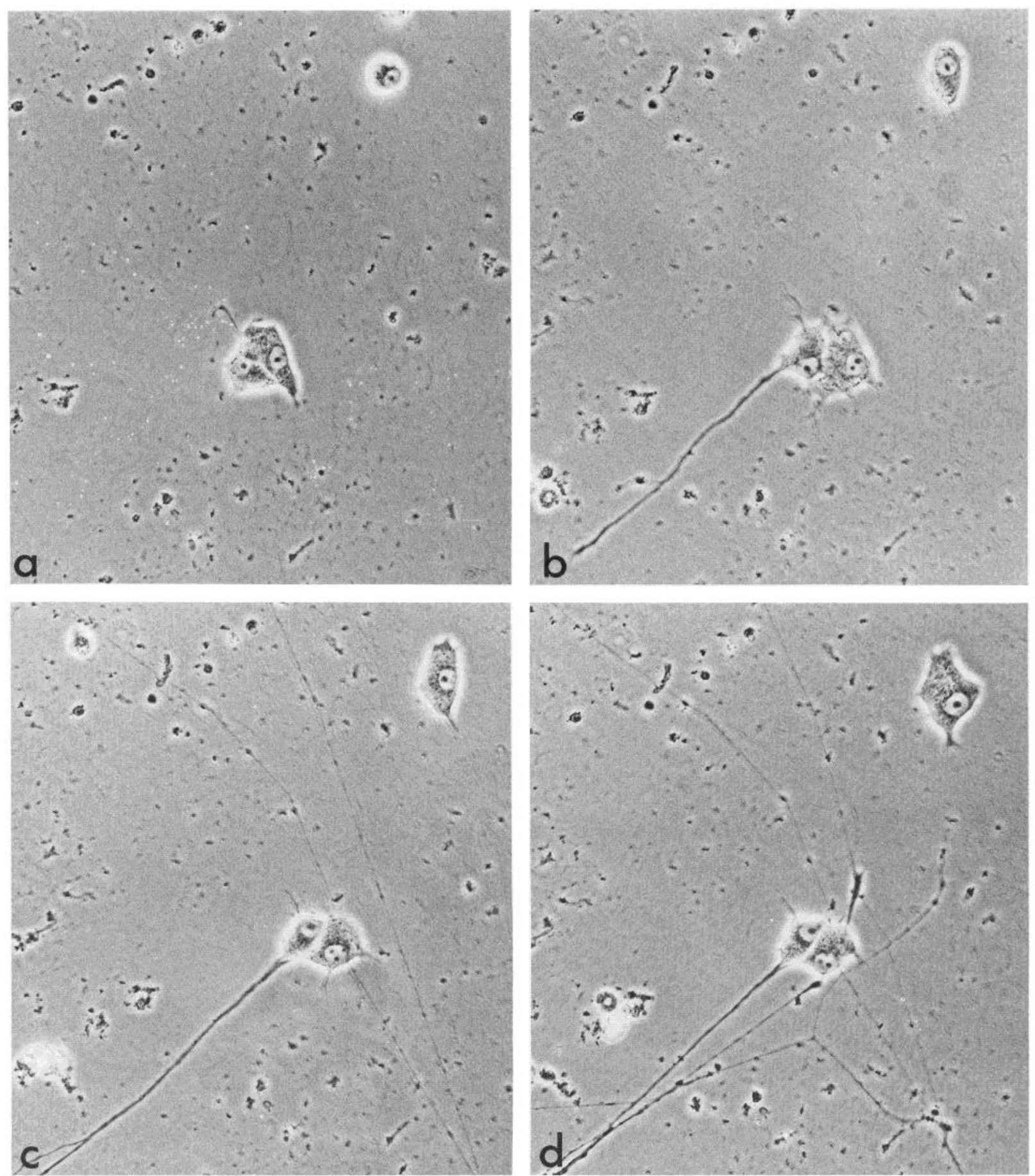

Figure 10. Conversion of identified SIF cells into neurons. $a$, Three SIF cells after 12 days in $5 \mu \mathrm{M}$ dexamethasone, at which point the corticosteroid was withdrawn and NGF was added. $b$, One day later; $c$, after 2 days; $d$, 3 days; $e, 5$ days; $f, 6$ days; $g, 9$ days; and $h, 13$ days. Magnification $\times 210$. The ultrastructure of these cells after 2 weeks in NGF is shown in Figures 12 and 13.

more cells with intermediate-sized granules. Because the cell number was always much lower in cultures grown in $10^{-8} \mathrm{M}$ hormone than in $5 \mu \mathrm{M}$ steroid, the absolute number of cells without PNMT immunoreactivity was similar in both conditions, but in $10^{-8} \mathrm{M}$ glucocorticoid the absolute number of PNMT-immunoreactive cells was much decreased. These effects of micromolar glucocorticoid on SIF cell morphology and transmitter chemistry are consistent with a number of experiments in vivo. Administration of glucocorticoids to newborn rats induces the appearance of PNMT and epinephrine in para-aortic bodies and in the SCG (Coupland and MacDougall, 1966; Eranko et al., 1966; Bohn et al., 1982). Dexamethasone treatment of pregnant rats can elicit PNMT-immunoreactive cells in the SCG as early as embryonic day 18.5 (Bohn et al., 1982). Administration of corticosteroid also prevents the normal postnatal degeneration of extraadrenal chromaffin tissue in the rat and induces the appearance of numerous chromaffin cells in ganglia where normally only occasional chromaffin cells are seen (Lempinen, 1964). Similarly, Eranko and Eranko (1972) observed that the numbers of SIF cells in rat SCG are increased 10 -fold in glucocorticoid hormone-treated rats. In organ culture, hydrocortisone also slightly increased the number and size of the granular vesicles (Eranko et al., 1972a, b). In all of these cases and in the dissociated cell cultures described here, high levels of glucocorticoid appear to shift the SIF cells toward a more type ॥ or adrenal chromaffin phenotype. 

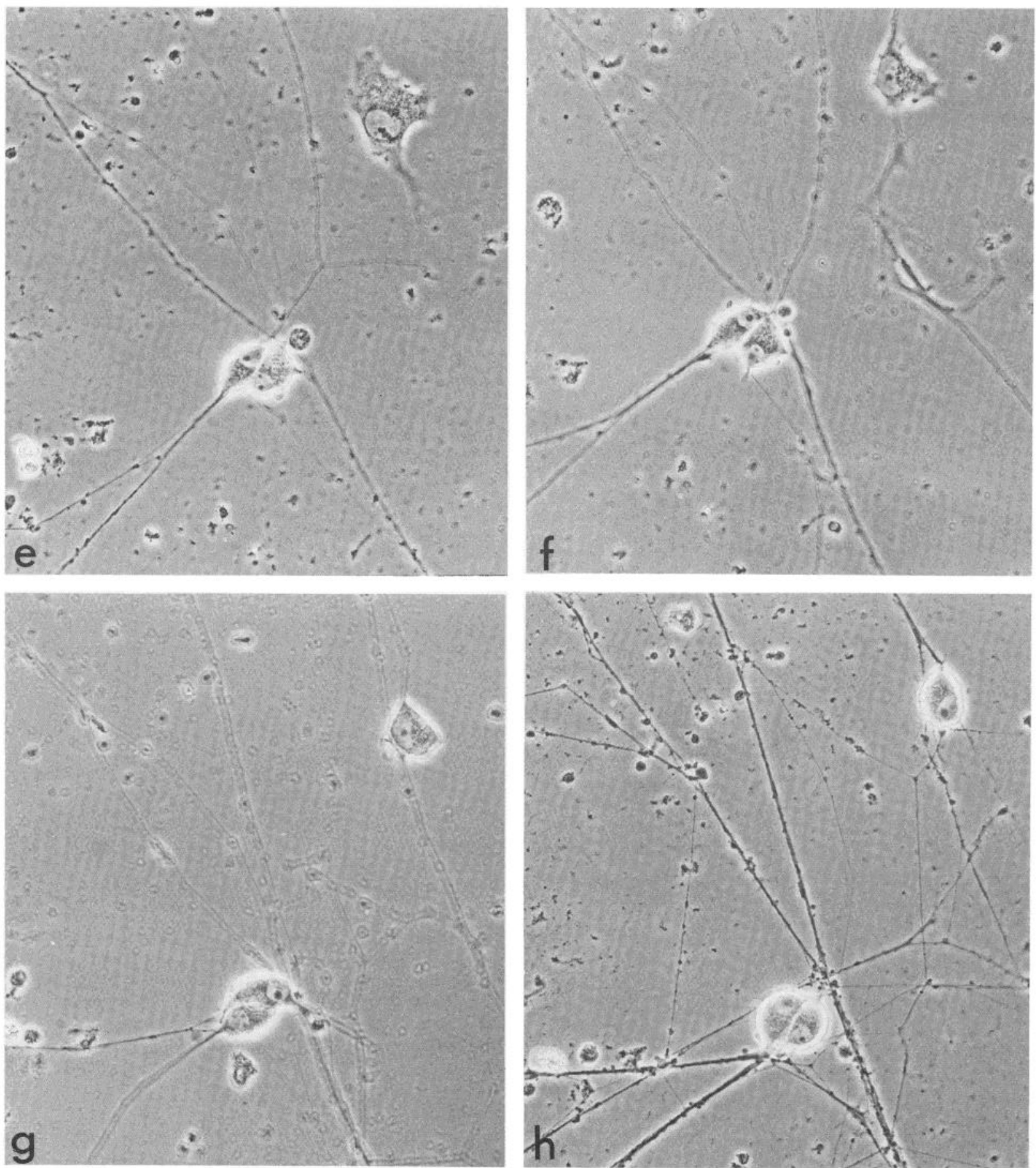

Figure 10

The addition of $\mathrm{CM}$ as well as $10^{-8} \mathrm{M}$ glucocorticoid to cultures from newborn rat SCG markedly potentiated the differentiation of type I SIF cells, that is, cells with granules of type I size, with short processes, and without PNMT immunoreactivity. Corticosteroid was still required, however; no SIF cells were observed in the presence of $\mathrm{CM}$ alone, and $\mathrm{CM}$ did not greatly alter cell survival in the presence of glucocorticoid. Even in a high concentration of hormone $(5 \mu \mathrm{M})$ as well as CM, most of the SIF cells also had type I-sized granules. Based on studies in vivo, it has been suggested that the predominant CA stored by cells with type I granules is dopamine, whereas cells with type II granules store norepinephrine or epinephrine (Lever et al., 1976; Taxi, 1979). The results with SIF cells grown with CM plus $5 \mu \mathrm{M}$ hormone show that this correlation does not always hold, since the majority of cells in these cultures had small type I granular vesicles but more than $60 \%$ of the cells were DBH and PNMT immunoreactive.

The factor in CM responsible for enhancing the development of type I SIF cells is unknown. An antiserum to NGF was always included in the medium to prevent survival of principal neurons, but a small amount of NGF activity might have persisted. CMs such as these are known to contain factors which enhance NGF responsiveness (see Doupe et al., 1985). Therefore, very low levels of NGF might still have had effects on the developing SIF cells. The fact that most of the cells in hormone plus CM had neurites may suggest an NGF-like activity. Alternatively, a different non-neuronal cell factor in the crude CM might act on SIF cell differentiation. This heart cell CM 

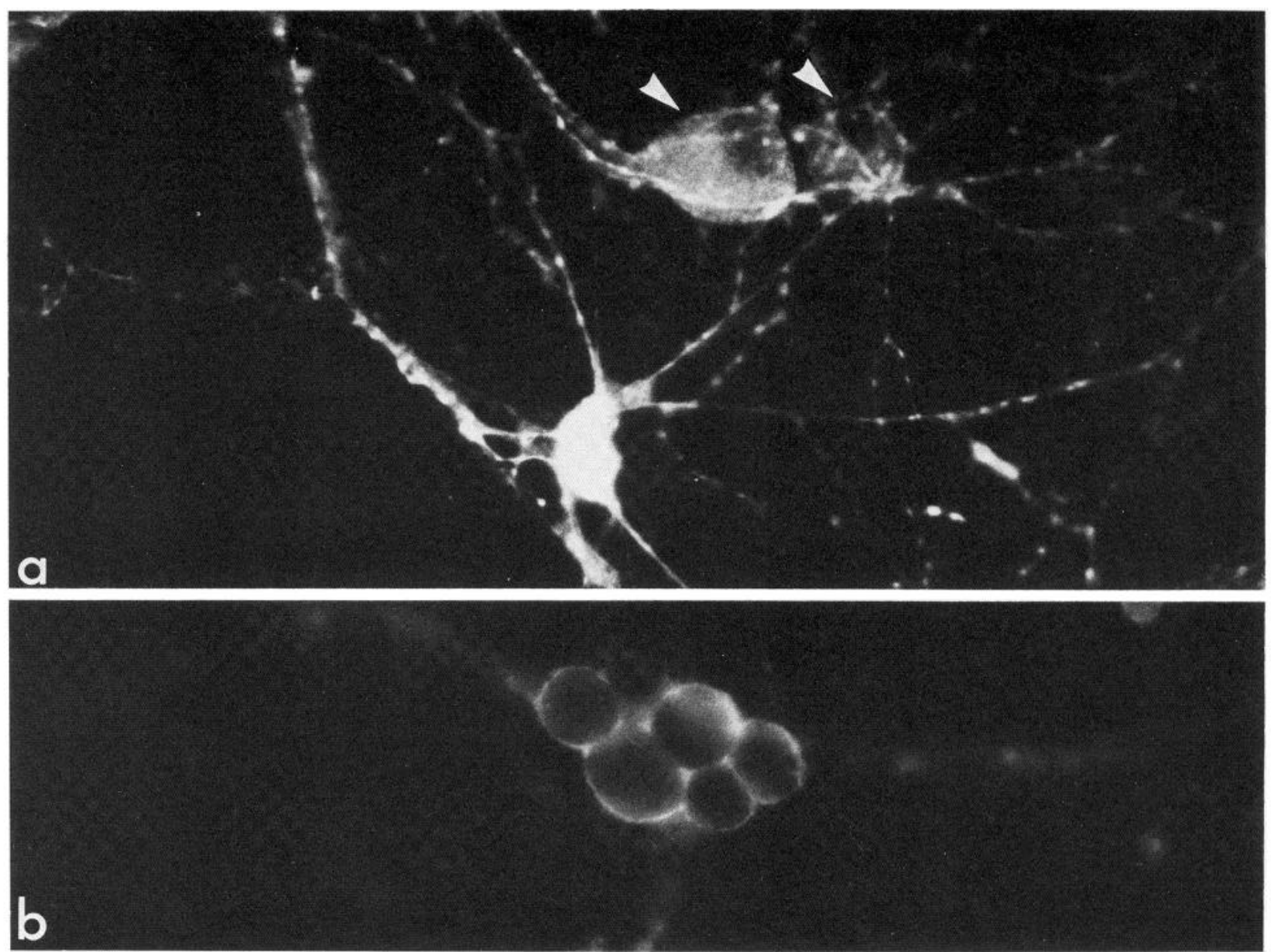

Figure 11. SIF cell-derived neurons. a, Two weeks after NGF addition, many cells no longer have intense CA fluorescence in their cell bodies (arrowheads), although they exhibit numerous fluorescent varicosities along their processes. Some brightly fluoresecent cells with neurites are also present in the cultures. $b$. The indirect immunofluorescence of tetanus toxin binding to SIF cell-derived neuronal cell bodies. Magnification $\times 420$.

is already known to contain both a cholinergic inducing activity (Patterson and Chun, 1977; Patterson, 1978) and a neurite-promoting factor(s) (see Doupe et al., 1985), and numerous other factors are undoubtedly present. Although the identity of the factor(s) is not clear, a combination of environmental factors including corticosteroid appears to promote the differentiation of the intermediate phenotype, the type I SIF cell. The location of many SIF cells in vivo around fenestrated blood vessels (Matthews and Raisman, 1969; McDonald and Blewett, 1981) may reflect their survival and differentiation in an environment where glucocorticoid acts in combination with other extracellular factors.

The results obtained here on the development of dissociated SIF cell cultures shed light on the question of how glucocorticoid increases SIF cell number in vivo. Lempinen (1964) hypothesized that the normal degeneration of extra-adrenal chromaffin tissue was caused by the fall in circulating corticosteroids seen shortly after birth, and was prevented by the administration of hydrocortisone. However, the appearance of new chromaffin cells and the hyperplasia of the para-aortic extra-adrenal chromaffin tissue are more difficult to explain by the prevention of degeneration alone. Similar questions can be asked about the glucocorticoid effect on PNMT induction in vivo (Bohn et al., 1982): is the glucocorticoid inducing PNMT in existing SIF cells, or is it allowing the survival of PNMT-containing SIF cells which would not normally survive the neonatal period? Our developmental time course experiments show that, although a small number of pre-existing SIF cells were present immediately after plating, the majority of SIF cells were differentiating in vitro. Moreover, the number of SIF cells generated was greater at higher glucocorticoid concentrations. This provides evidence that glucocorticoid can act to induce the formation of new SIF cells from precursors. Large granular vesicles and PNMT immunoreactivity were also not present at early times and thus were induced in vitro as well. In our dissociated cell cultures, the possibility of mitosis was excluded, since the culture conditions eliminated rapidly dividing cells. The precise nature of the SIF cell precursor in these cultures is unknown. It could be (i) a neuroblast the fate of which is changed by the hormonal environment, (ii) a committed SIF cell precursor which is completing differentiation, or (iii) an uncommitted sympathoadrenal precursor (perhaps a neural crest cell) which is instructed to become an SIF cell. In addition to inducing SIF cells, glucocorticoids also influenced survival: withdrawal of glucocorticoid from mature SIF cell cultures resulted in cell loss, as described for adrenal chromaffin cells.

In these experiments it is clear that most of the differentiated sympathetic principal neurons in the newborn SCG did not undergo conversion to SIF cells but died in the absence of NGF. The strict dependence of sympathetic neurons on NGF for survival complicates the question of whether the neuronal phenotype is a terminally differentiated state. In the preceding paper (Doupe et al., 1985) adrenal chromaffin cells were found to become dependent on NGF soon after responding to it, even at early times during the conversion to the neuronal phenotype. It would be very useful to develop conditions under which neurons could survive without including NGF with its instructive actions on the neuronal phenotype.

Differentiated SIF cells in culture responded to the withdrawal of corticosteroid and the administration of NGF by converting into neurons. One advantage of these pure dissociated cell cultures is that we could follow the transformation of individual identified SIF 


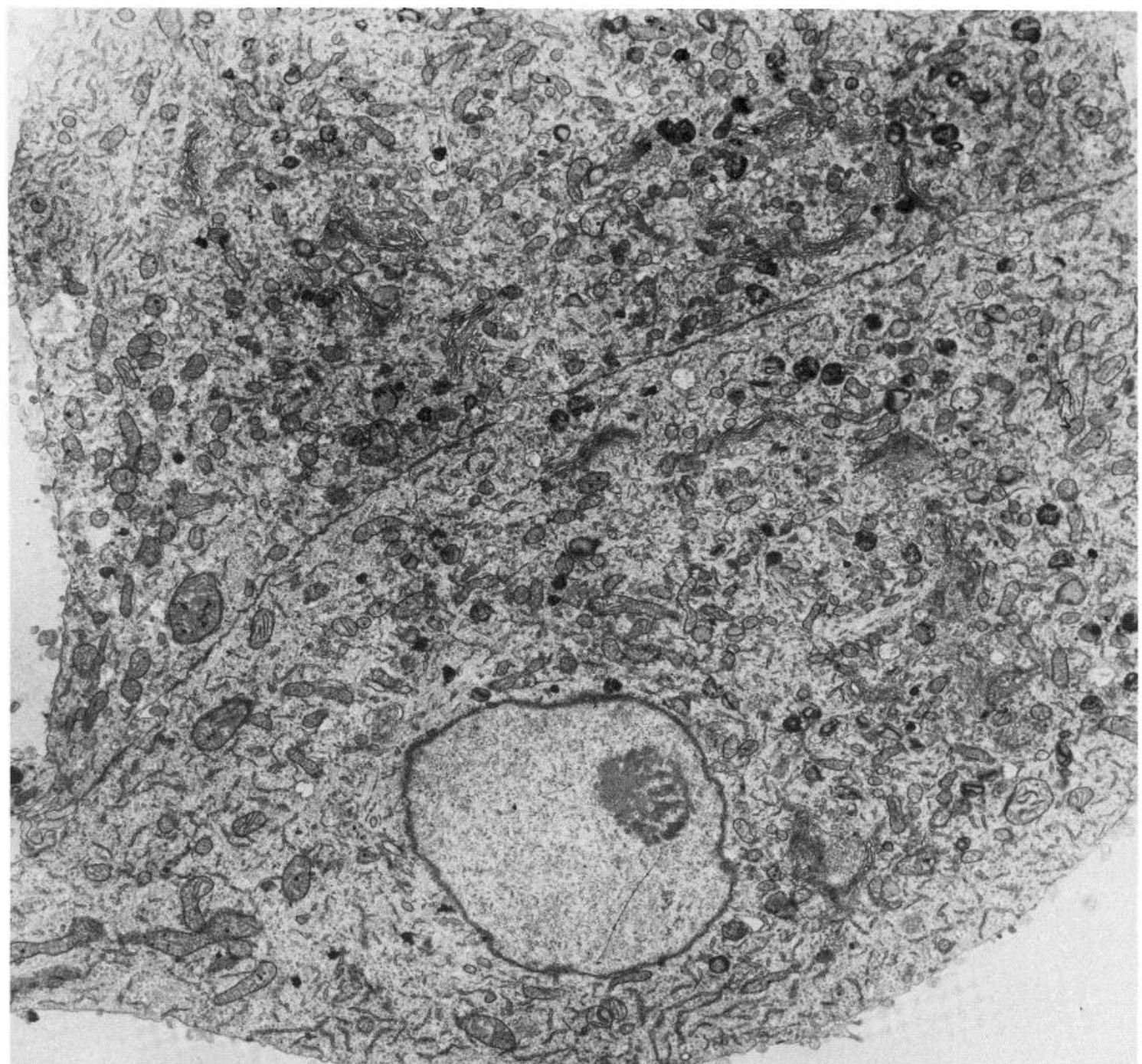

Figure 12. Ultrastructure of identified SIF cells. The two cells which were grouped together in Figure 10 are seen here to have characteristic neuronal ultrastructure. Magnification $\times 11,800$.

cells in the phase microscope for several weeks, and then examine them ultrastructurally (Figs. 10, 12, and 13). In addition to losing SIF cell properties such as intense cell soma CA fluorescence and large granular vesicles, the cells acquired long processes, characteristic neuronal ultrastructure and cell surface molecules, and formed morphologically specialized synapses. Thus, there are cells in newborn rat SCG with the potential to become either SIF cells or neurons, and glucocorticoids and NGF influence this choice. As described for adrenal chromaffin cells in NGF (Doupe et al., 1985), type II SIF cells transiently acquired vesicles of type I size during the conversion to neurons. Moreover, some of the cells which did not completely assume a neuronal phenotype in the presence of NGF also had both neurites and intermediate-sized granular vesicles, as did many of the cells in mature SIF cell cultures switched to medium containing both NGF and dexamethasone. This suggests that other sources of the type I SIF cell phenotype are SIF cells in transition to neurons as well as cells exposed to conflicting signals such as NGF and glucocorticoid in combination. The interaction of glucocorticoids, NGF, and the factor(s) in CM thus allowed a variety of SIF cell types to be grown from the same population of precursors. Similar interactions in vivo, as well as the changing serum levels of glucocorticoids during early development (e.g., Allen and Kendall, 1967; Martin et al., 1977), could account for the diversity of SIF cells in number and type.

A number of our results are consistent with the idea (originially derived from morphological studies) that SIF cells are intermediate in phenotype between neurons and chromaffin cells. Compared to adrenal chromaffin cells, a higher percentage of SIF cells responded to NGF with neuronal conversion, and this conversion was also more rapid: morphologically specialized synapses were formed in SIF cell cultures after 2 weeks with NGF but do not appear in adrenal chromaffin cell cultures until NGF has been present for 4 to 6 weeks. Furthermore, the inclusion of glucocorticoid as well as NGF in mature SIF cell cultures did not inhibit the NGF-induced neurite outgrowth and neuronal conversion as much as it does for chromaffin cells. Thus SIF cells are more readily pushed toward a neuronal phenotype than are chromaffin cells. The fact that a higher percentage of SIF cells bound detectable amounts of tetanus toxin in the absence of NGF than do chromaffin cells might also be viewed as an intermediate characteristic (Doupe et al., 1985)

The results presented in this and the preceding paper (Doupe et al., 1985) further amplify the role of environmental factors in the development of neural crest derivatives. Individual cells can be converted from one phenotype into another, even after they have embarked on a particular pathway of differentiation. The interrelationships of these phenotypes are summarized in the lineage diagram shown in Figure 15: in the presence of glucocorticoid, an apprently undifferentiated precursor cell can become an SIF cell. The gluococorticoid hormone concentration and a non-neuronal cell factor influence the types of SIF cell formed, with high hormone 

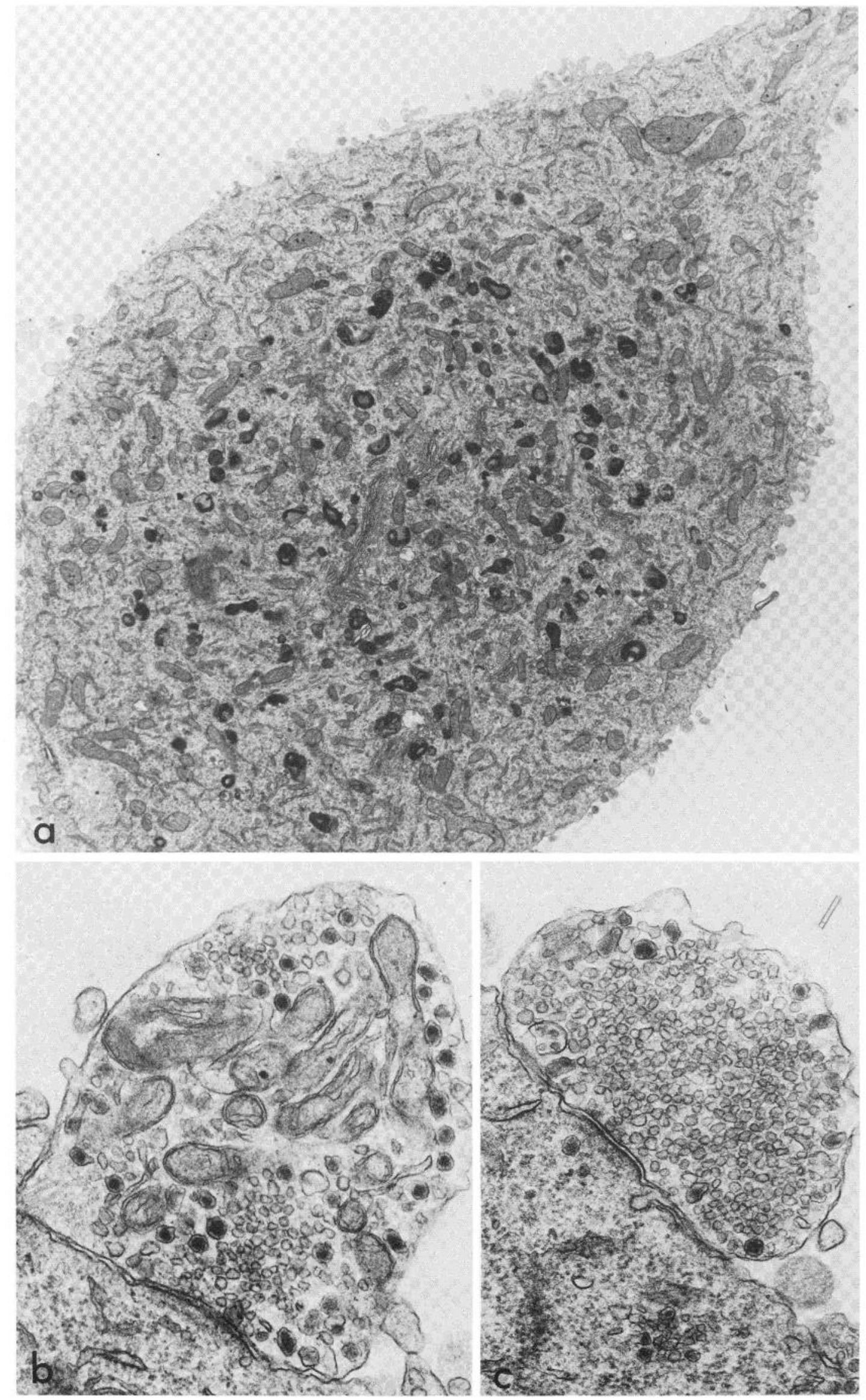

Figure 13. Ultrastructure of identified SIF cells. The solitary cell in Figure 10 has neuronal ultrastructure, as shown in $a$ (magnification $\times 11,800$ ), and in other sections is observed to received synapses, shown in $b$ and $c$ (magnification $\times 43,700$ ). Note that the cell also has a small cluster of granules in the cell body, as occasionally observed in sympathetic principal neurons. 


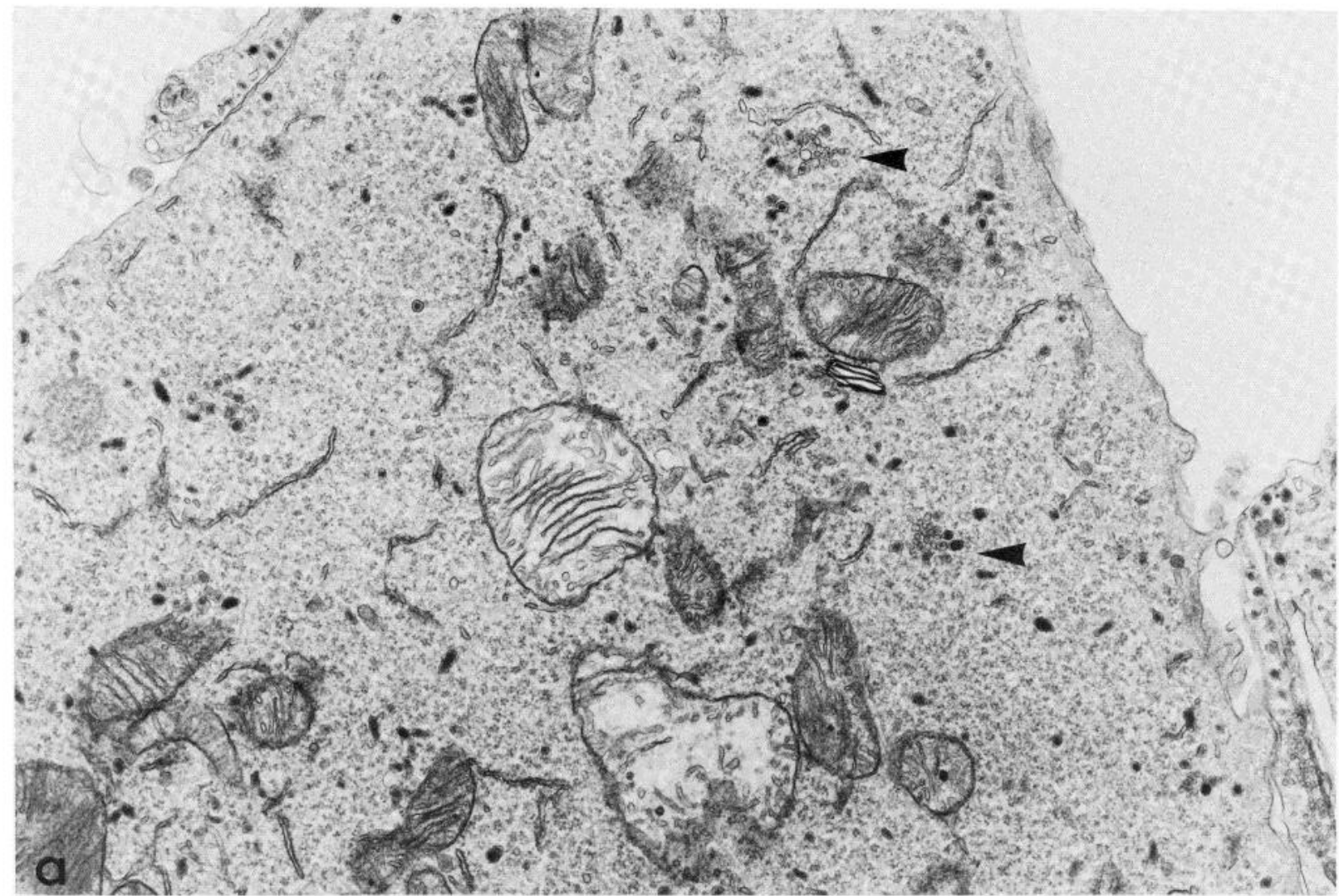

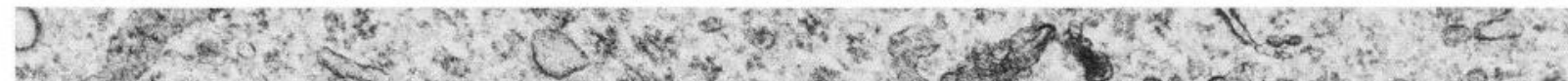

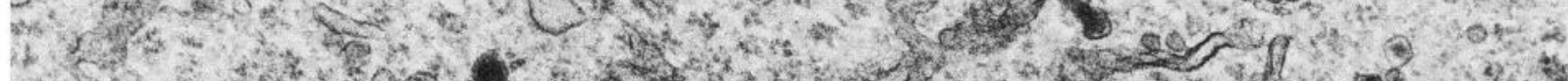

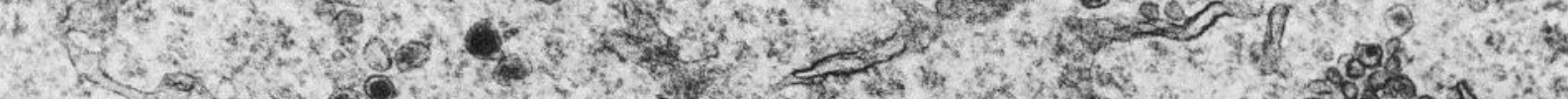
a.

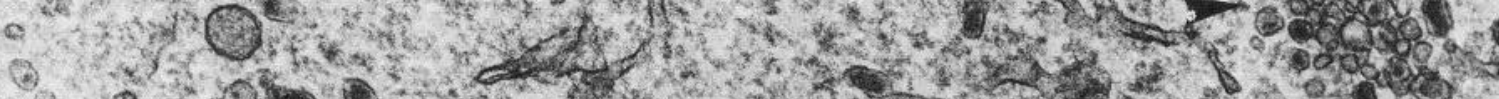

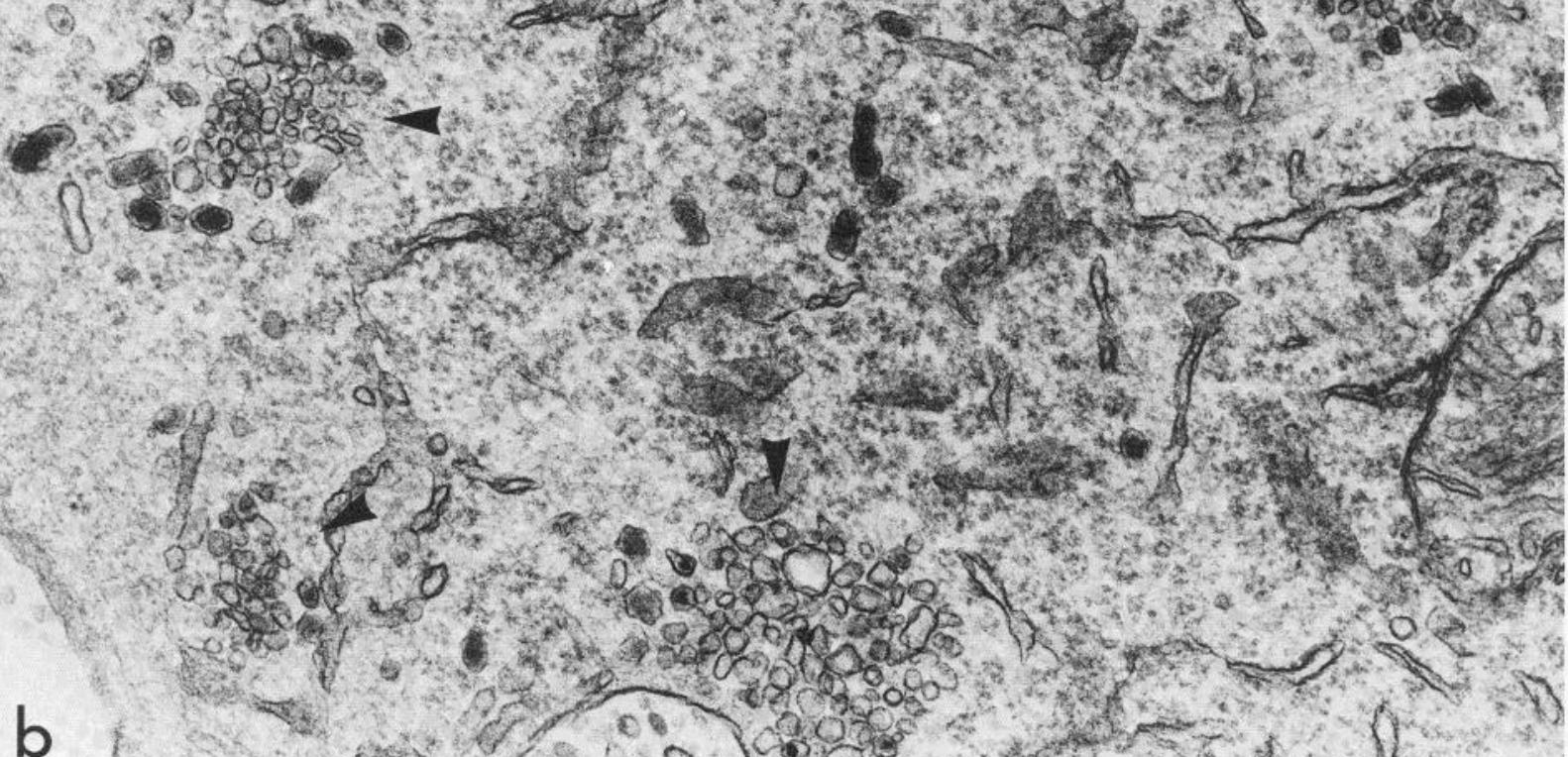

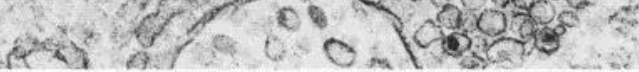

Figure 14. Ultrastructure of SIF cells switched to medium containing dexamethasone as well as NGF. a, Cells have neurites and increased amounts of rough endoplasmic reticulum but also contain numerous small granular vesicles of type I size, and clusters of small synaptic-sized vesicles (arrowheads) Magnification $\times 11,800$. $b$, The clusters of intermediate-sized and small synaptic vesicles at higher magnification. Magnification $\times 43,700$. 
TABLE ॥

Influence of glucocorticold, CM, and NGt on SIt cell properties

SIF cell cultures were grown for $3^{1 / 2}$ weeks in $5 \mu \mathrm{M}$ dexamethasone (line 1), or switched out of steroid at day 12 and grown in NGF alone (line 2), in CM plus NGF (line 3), or in NGF plus $5 \mu \mathrm{m}$ dexamethasone (line 4). Column 2 represents the percentage of the population with long neurites, column 3 gives the percentage that displayed tetanus toxin binding, and column 4 gives the percentage of cells with intense catecholamine fluorescence.

\begin{tabular}{lccc}
\hline & $\begin{array}{c}\text { Percentage } \\
\text { with } \\
\text { Processes }\end{array}$ & $\begin{array}{c}\text { Percentage } \\
\text { Tetanus } \\
\text { Toxint }\end{array}$ & $\begin{array}{c}\text { Percentage } \\
\text { CA Fluorescent }\end{array}$ \\
\hline +dex & $15.0 \pm 4.8$ & $56.4 \pm 4.5$ & $93.4 \pm 1.4$ \\
& $(n=5)^{b}$ & $(n=3)$ & $(n=5)$ \\
-dex - CM + NGF & $82.4 \pm 5.9$ & $89.6 \pm 5.2$ & $53.5 \pm 13.9$ \\
& $(n=5)$ & $(n=5)$ & $(n=5)$ \\
-dex + CM + NGF & $96.9 \pm 0.8$ & $\mathrm{ND}$ & $\mathrm{ND}$ \\
& $(n=5)$ & & \\
+dex - CM + NGF & $53.8 \pm 3.8$ & $64.5 \pm 6.6$ & $69.1 \pm 9.1$ \\
& $(n=5)$ & $(n=5)$ & $(n=5)$ \\
\hline
\end{tabular}

${ }^{a}$ dex, dexamethasone.

${ }^{b} n$, number of cultures tested.

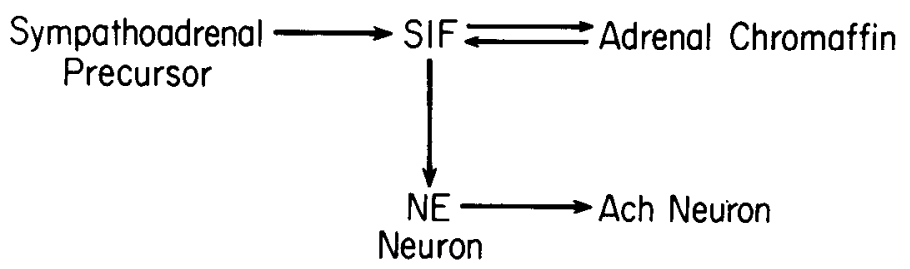

Figure 15. Phenotypic interconversions of adrenergic neural crest derivatives $m$ vitro and hypothetical lineage diagram tor the autonomic nervous system in vivo. NE, norepinephrine; Ach, acetylcholine.

levels inducing an adrenal chromaffin cell (or type II SIF cell) phenotype, presumably just as the corticosteroid-rich environment of the adrenal medulla does in vivo. In the presence of NGГ, SIT cells and adrenal chromaffin cells can become neurons, and this process is greatly enhanced by a neurite-promoting factor produced by nonneuronal cells. During the conversion, adrenal chromaffin cells temporarily acquire some SIF cell characteristics, notably intermediatesized CA granules, suggesting that an SIF cell is the intermediate form in this transition. Other transitional cells have Type I granules as well, including SIF cells switched to medium containing both glucocorticoid and NGF, and chromaffin cells from adult rats which are only partially converted to neurons. Adrenal chromaffin cells can further progress to a cholinergic neuronal phenotype, apparently passing through an adrenergic neuronal stage before becoming cholinergic.

The central position of SIF cells in these phenotypic interconversions in vitro suggests that they may be the developmental precursor for all of the derivatives of the sympathoadrenal lineage (Landis and Patterson, 1981). Thus, the interconversions seen in vitro could represent more than just the developmental potentiality that these cells possess. As in the case of the adrenergic to cholinergic conversion of neurons initially demonstrated in culture and then found to occur during the normal development of some sympathetic neurons in vivo (Landis and Keefe, 1983), perhaps the SIF cell conversions also represent stages of normal development in this lineage. Several in vivo observations are consistent with the possibility that SIF cells are the precursors of both sympathetic neurons and chromaffin cells. The cells that initially populate sympathetic ganglia and invade the adrenal cortex have intense CA fluorescence (Enemar et al., 1965; de Champlain et al., 1970; Owman et al., 1971; Kirby and Gilmore, 1976). In embryonic rat adrenal medullae (Diner, 1965; Elfvin, 1967; Millar and Unsicker, 1981) and in sympathetic ganglia, at least in chicks (Wechsler and Schmekel, 1967; LuckenbillEdds and Van Horn, 1980), these cells contain dense-cored granular vesicles of the type I SIF cell size. Neural crest cells that develop CA synthesis in culture also have granular vesicles similar to those of SIF cells (Sieber-Blum et al., 1981), which increase in size with exposure to glucocorticoid (Smith and Fauquet, 1981). With further development in vivo, the granules of embryonic adrenal medullary cells increase in size to the diameter of mature chromaffin granules (Diner, 1965; Elfvin, 1967; Millar and Unsicker, 1981). In contrast, the number of cells with intensive fluorescence and large granular vesicles is reduced during further development of autonomic ganglia (Owman et al., 1971; Kirby et al., 1980). The brightly fluorescent cells in ganglia could be dying but might also be undergoing a conversion to neurons. In both chicks (Kirby et al., 1980) and rats (Owman et al., 1971) many of these cells are sprouting fluorescent processes at the time when the number of fluorescent cell bodies begins to decrease. On this hypothesis, developing cells that ended up near fenestrated blood vessels, where corticosteroid levels could compete with local NGF, would be stabilized in the intermediate or precursor phenotype, the SIF cell. It would be of interest to determine whether SIF cells from adult SCG could respond to the same range of factors as cells from neonates, or have become committed to the intermediate phenotype. The apparently undifferentiated precursor cells observed in the newly plated cultures described here could represent a few persistent neural crest cells. These precursors are certainly few in number, as plating approximately $10^{5}$ cells from the SCG gives rise to only several hundred SIF cells. It is intriguing that the idea of SIF cells as neuronal precursors has been raised in the context of phylogenetic development as well. The hearts of simple vertebrates such as the cyclostomes contain large amounts of CA as do the hearts of reptiles, birds, and mammals, but in contrast to other vertebrates, there are no neurons or neuronal terminals in the heart (Lignon and Le Douarin, 1978). Instead, all of the aminergic cells are SIF cells, many with processes, containing large granular vesicles like those of mammalian SIF cells (Bloom et al., 1961; Lignon and Le Douarin, 1978). This suggests that these cells may be phylogenetic precursors of the neurons of the sympathetic system (Taxi et al., 1983).

There is a subset of sympathetic neurons, the so-called "short" adrenergic neurons of the urogenital tract (Owman et al., 1974), which, although they morphologically resemble neurons, share certain unusual properties with SIF and adrenal chromaffin cells: they are more resistant to reserpine, 6-hydroxydopamine (Baumgarten et al., 1975), and immunosympathectomy with antiserum to NGF (Zaimis et al., 1965) than are ordinary "long" adrenergic neurons. Furthermore, they show a remarkable sensitivity to sex steroids (Sjostrand and Swedin, 1976; Owman and Sjoberg, 1977; Partancn and Hervonen, 1979). It remains to be seen whether short adrenergic neurons are in some way developmentally closer to SIF and adrenal chromaffin cells than to other sympathetic neurons.

SIF cells are also found in parasympathetic ganglia (Jacobowitz, 1967; Ehinger and Falck, 1970; Jacobowil< el al., 1973); thus, the postulated role of the SIF cell as precursor could be extended to the development of cholinergic parasympathetic neurons. Consistent with this idea is the conversion of chromaffin cells in vitro into a cholinergic neuronal phenotype (Ogawa et al., 1984; Doupe et al., 1985). Ihe transient presence of catecholaminergic cells in early gut (Cochard et al., 1978, 1979; Jonakait et al., 1979; Teitelman et al., 1978, 1979; Cochard, 1981) and the response of these cells to corticosteroid (Jonakait et al., 1980) are consistent with a role of SIF-like cells as precursors in enteric ganglia as well. Finally, this way of looking at SIF cells in the adult, as the vestige of an earlier developmental stage responsive to the environment, may explain why the numbers and types of SIF cells are so variable from species to species (Coupland, 1965b; Taxi, 1979), from ganglion to ganglion (Lever et al., 1976; Lu et al., 1976), and even from animal to animal (Tomasulo et al., 1982). 


\section{References}

Allen, C., and J. W. Kendall (1967) Maturation of the circadian rhythm of plasma corticosterone in the rat. Endocrinology 80: 926-930.

Alue, L., dild R. Levi-Montalcini (1979) Nerve growth factor-induced transformation of immature chromaffin cells in vivo into sympathetic neurons: Effect of antiserum to nerve growth factor. Proc. Natl. Acad. Sci. U. S. A. 76: $1246-1250$.

Aloe, L., and R. Levi-Montalcini (1980) Comparative studies on the effects elicited by pre- and postnatal injections of anti-NGF, guanethidine, and 6 hydroxydopamine in chromaffin cells and ganglion cells of the adrenal medulla and carotid body in infant rats. Adv. Biochem. Psychopharmacol. 25: $221-226$

Baumgarten, H. G., C. Owman, and N. -O. Sjoberg (1975) Neural mechanisms in male fertility. In Control of Male Fertility, J. J. Sciarra, C. Markland, and J. J. Speidel, eds., pp. 26-40, Harper and Row, Hagerstown, MD.

Bjorklund, A., L. Cegrell, B. Falck, M. Ritzen, and E. Rosengren (1970) Dopamine-containing cells in sympathetic ganglia. Acta Physiol. Scand. 78: 334-338

Bloom, G., E. Ostlund, U. S. von Euler, F. Lishajko, M. Ritzen, and J. AdamsRay (1961) Studies on catecholamine-containing granules of specific cells in cyclostome hearts. Acta Physiol. Scand. 53 (Supp/. 85): 1-34.

Bohn, M. C., M. Goldstein, and I. B. Black (1982) Expression of phenylethanolamine $\mathrm{N}$-methyltransterase in rat sympathetic ganglia and extra-adrenal chromaftin tissue. Dev. Biol. 89: 299-308.

Chun, L. L. Y., and P. H. Patterson (1977) Role of nerve growth factor in the development of rat sympathetic neurons in vitro. III. Effect on acetylcholine production. J. Cell Biol. 75: 712-718.

Ciaranello, R. D., D. Jacobowitz, and J. Axelrod (1973) Effect of dexamethasone on phenylethanolarnine-n-methyltransferase in chromaffin tissue of the neonatal rat. J. Neurochem. 20: 799-805.

Cochard, P. (1984) Les cellules à phenotype adrenergique transitoire de l'intestin embryonnaire des rongeurs sont de nature neuronale. C. H. Acad. Sci. Paris 299: 209-214.

Cochard, P., M. Goldstein, and I. B. Black (1978) Ontogenetic appearance and disappearance of tyrosine hydroxylase and catecholamines in the rat embryo. Proc. Natl. Acad. Sci. U. S. A. 75: 2986-2990

Cochard, P., M. Goldstein, and I. B. Black (1979) Initial development of the noradrenergic phenotype in autonomic neuroblasts of the rat embryo in vivo. Dev. Biol. 71: 100-114.

Coupland, R. C. (1965a) The Natural History of the Chromaffin Cell, Long mans \& Green, London

Coupland, R. E. (1965b) Electron microscopic observations on the structure of the rat adrenal medulla. J. Anat. 99: 231-254.

Coupland, R. E., and J. D. B. MacDougall (1966) Adrenaline formation in noradrenalin-storing chromaffin cells in vitro induced by corticosterone. J. Endocrinol. 36: 317-324.

Coupland, R. E., S. Kobayashi, and A. Tomlinson (1977) On the presence of small granule chromaftin (SGC) cells in the rodent adrenal medulla. J. Anat. 124: 488-489.

Coupland, R. E., S. Kobayashi, Y. Serizawa, and T. Fujita (1978) SGC: The third type of adrenal chromaffin cell. In Catecholamines-Basic and Clinical Frontiers, E. Usdin, I. J. Kopin, and J. Barchas, eds., pp. 313315, Pergamon Press, New York.

Dall, W. G., A. F. Evan, and H. R. Eason (1975) The major ganglion in the pelvic plexus of the male rat. A histochemical and ultrastructural study. Cell Tissue Res. 159: 49-62.

de Champlain, J., T. Malmfors, L. Olson, and C. Sachs (1970) Ontogenesis of peripheral adrenergic neurons in the rat: Pre-and postnatal observations. Acta Physiol. Scand 80: 276-288.

Diner, O. (1965) Observations sur le developpement de la medullo-surrenale du rat: l'evolution de la partie non chromaffine. Arch. Anat. Microsc. 54: $671-718$

Doupe, A. J., and P. H. Patterson (1980) Glucocorticoids and the developing nervous system. In Current Topics in Neuroendocrinology, D. Ganten and D. Ptatt, eds., Vol. 2, pp. 23-43, Springer-Verlag, Berlin.

Doupe, A. J., P. H. Patterson, and S. C. Landis (1980) Dissociated cell culture of SIF cells: Hormone dependence and NGF action. Soc. Neurosci. Abstr. 6: 409.

Doupe, A. J., S. C. Landis, and P. H. Patterson (1985) Environmental influences in the development of neural crest derivatives: Glucocorticoids, growth factors, and chromaffin cell plasticity. J. Neurosci. 5: 2119-2142.

Ehinger, B., and B. Falck (1970) Uptake of some catecholamines and their precursors into neurons of the rat ciliary ganglion. Acta Physiol. Scand. 78: $132-141$
Elfvin, L. G. (1967) The development of the secretory granules in the rat adrenal medulla. J. Ultrastruct. Res. 17: 45-62.

Elfvin, L. G., T. Hokfelt, and M. Goldstein (1975) Fluorescence microscopical, immunohistochemical and ultrastructural studies on sympathetic ganglia of the guinea pig, with special reference to the SIF cells and their catecholamine content. J. Ultrastruct. Res. 51: 377-396.

Enemar, A., B. Falck, and R. Hakanson (1965) Observations on the appearance of norepinephrine in the sympathetic nervous system of the chick embryo. Dev. Biol. 11: 268-283.

Eranko, L., and O. Eranko (1972) Effect of hydrocortisone on histochemically demonstrable catecholamines in the sympathetic ganglia and extra-adrenal chromaffin tissue of the rat. Acta Physiol. Scand. 84: 125-133.

Eranko, O., and M. Harkonen (1963) Histochemical demonstration of fluorogenic amines in the cytoplasm of sympathetic ganglion cells of the rat. Acta Physiol. Scand. 58: 285-286.

Eranko, O., and M. Harkonen (1965) Monoamine-containing small cells in the superior cervical ganglion of the rat and an organ compared of them. Acta Physiol. Scand. 63: 511-512.

Eranko, O., M. Lempinen, and L. Raisanen (1966) Adrenaline and noradrenaline in the organ of Zuckerkandl and adrenals of newborn rats treated with hydrocortisone. Acta Physiol. Scand. 66: 253-254.

Eranko, O., L. Eranko, C. E. Hill, and G. Burnstock (1972a) Hydrocortisoneinduced increase in the number of small intensely fluorescent cells and their histochemically demonstrablc catecholamine content in culturcs of sympathetic ganglia of the newborn rat. Histochem. J. 4: 49-58.

Eranko, O., J. Heath, and L. Eranko (1972b) Effect of hydrocortisone on the ultrastructure of the small, intensely fluorescent, granule-containing cells in cultures of sympathetic ganglia of newborn rat. Z. Zellforsch. 134: 297310.

Fujii, D. K., S. L. Massoglia, N. Savion, and D. Gospadarowicz (1982) Neurite outgrowth and protein synthesis by PC12 cells as a function of substratum and nerve growth factor. J. Neurosci. 2: 1157-1175.

Fuxe, K., M. Goldstein, T. Hokfelt, and T. H. Joh (1971) Cellular localization of dopamine-B-hydroxylase and phenylethanolamine- $N$-methyltransferase as revealed by immunohistochemistry. Prog. Brain Res. 34: 1217-1238.

Grillo, M. A. (1966) Electron microscopy of sympathetic tissues. Pharmacol. Rev. 18: 387-399.

Grynszpan-Winograd, O. (1975) Ultrastructure of the chromaffin cell. In Handbook of Physiology. Section 7: Endocrinology, Adrenal Gland, Vol. VI: H. Blaschko, G. Sayers, and A. D. Smith, eds., pp. 295-308, American Physiological Society, Bethesda, MD

Hellstrom, S. (1975) Morphometric studies of dense-cored vesicles in Type I cells of rat carotid body. J. Neurocytol. 4:77-86.

Jacobowitz, D. M. (1967) Histochemical studies of the relationship of chromaffin cells and adrenergic nerve fibers to the cardiac ganglia of several species. J. Pharmarol Fxp. Ther. 158: ?27-240.

Jacobowitz, D. M., and L. A. Greene (1974) Histofluorescence study of chromaffin cells in dissociated cell cultures of chick embryo sympathetic ganglia. J. Neurobiol. 5: 65-83.

Jacobowitz, D. M., K. M. Kent, J. H. Fleisch, and T. Cooper (1973) Histofluorescent study of catecholamine-containing elements in cholinergic ganglia from the calf and dog lung. Proc. Soc. Exp. Biol. Med. 144: 464-466.

Jonakait, G. M., J. Wolf, P. Cochard, M. Goldstein, and I. B. Black (1979) Selective loss of noradrenergic phenotypic characters in neuroblasts of the rat embryo. Proc. Natl. Acad. Sci. U. S. A. 76: 4683-4686.

Jonakait, G. M., M. C. Bohn, and I. B. Black (1980) Maternal glucocorticoid hormones influence neurotransmitter phenotypic expression in embryos. Science 210: 551-553.

Jones, M. T., E. W. Hillhouse, and J. L. Burden (1977) Dynamics and mechanics of corticosteroid feedback at the hypothalamus and anterior pituitary gland. J. Endocrinol. 73: 405-417.

Kirby, M. L., and S. A. Gilmore (1976) A correlative histofluorescence and light microscopic study of the formation of the sympathetic trunks in chick embryos. Anat. Rec. 186: 437-450.

Kirby, M. L., J. W. McKenzie, and T. A. Weidman (1980) Developing innervation of chick heart: A histofluorescence and light microscopic study of sympathetic innervation. Anat. Rec. 196: 333-340.

Kobayashi, S. (1971) Comparative cytological studies of the carotid body. I. Demonstration of monoamine-storing cells by correlated chromaffin reaction and fluorescence histochemistry. Arch. Histol. Jpn. 33: 319-339.

Landis, S. C., and D. Keefe (1983) Fvidence for neturotransmitter plasticity in vivo: Developmental changes in properties of cholinergic sympathetic neurons. Devel. Biol. 98: 349-372.

Landis, S. C., and P. H. Patterson (1981) Neural crest cell lineages. Trends Neurosci. 4: 172-175. 
Le Douarin, N., and M. -A. Teillet (1974) Experimental analysis of the migration and differentiation of neuroblasts of the autonomic nervous system and of neuroectodermal mesenchymal derivatives using a biological cell marking technique. Dev. Biol. 41: 162-184.

Lempinen, M. (1964) Extra-adrenal chromaffin tissue of the rat and the effect of cortical hormones on it. Acta Physiol. Scand. 62 (Suppl. 231): 1-91.

Lever, J. D., R. M. Santer, K. -S. Lu, and R. Presley (1976) Chromaffinpositive and small intensely fluorescent cells in normal and amine-depleted sympathetic ganglia. In Chromatfin, Enterochromatfin and Related Cells, R. E. Coupland and T. Fujita, eds., pp. 83-93, Elsevier-North Holland Publishing Co., Amsterdam.

Lietzke, R. and K. Unsicker (1983) Tetanus toxin binding to different morphological phenotypes of cultured rat and bovine adrenal medullary cells. Neurosci. Lett. 38: 233-238.

Lignon, L., and G. Le Douarin (1978) Smalt intensely fluorescent (SIF) cells and myocardiac cells in the ammocoete heart: A correlative histofluorescence, light and electron microscopic study with special reference to the action of reserpine. Biol. Cell 31: 169-176.

Lu, K. S., J. D. Lever, R. M. Santer, and R. Presley (1976) Small granulated cell types in rat superior cervical and coeliac-mesenteric ganglia. Cell Tissue Res. 172: 331-343.

Luckenbill-Edds, L., and C. Van Horn (1980) Development of chick paravertebral sympathetic ganglia. I. Fine structure and correlative histofluorescence of catecholaminergic cells. J. Comp. Neurol. 191: 65-76.

Mains, R. E., and P. H. Patterson (1973) Primary cuitures of dissociated sympathetic neurons. 1. Establishment of long-term growth in culture and studies of differentiated properties. J. Cell Biol. 59: 229-245.

Martin, C. E., M. H. Cake, P. E. Hartmann, and I. R. Cook (1977) Relationship between fetal corticosteroids, maternal progesterone and parturition in the rat. Acta Endocrinol. 84: 167-176.

Matthews, M. R., and G. Raisman (1969) The ultrastructure and somatic efferent synapses of small granule-containing cells in the superior cervica ganglion. J. Anat. 105: 255-282.

McDonald, D. M., and R. W. Blewett (1981) Location and size of carotid body-like organs (paraganglia) revealed in rats by the permeability of blood vessels to Evans blue dye. J. Neurocytol. 10: 607-643.

Millar, T. J., and K. Unsicker (1981) Catecholamine-storing cells in the adrenal medulla of the pre- and postnatal rat. Coll Tissuc Ros. 217: 155170.

Norberg, N. -O., M. Ritzen, and N. Ungerstedt (1966) Histochemical studies on a special catecholamine-containing cell type in sympathetic ganglia Acla Pliysiol. Scarid. 67: 260-270.

Ogawa, M., T. Ishikawa, and A. Irimajiri (1984) Adrenal chromaffin cells form functional cholinergic synapses in culture. Nature 307: 66-68.

Oison, L. (1970) Fluorescence histochemical evidence for axonal growth and secretion from transplanted adrenal medullary tissue. Histochemie 22 $1-7$

Owman, C., and N. - O. Sjoberg (1977) Influence of pregnancy and sex hormones on the system of short adrenergic neurons in the female reproductive tract. In Proceedings of the 5th International Congress of Endocrinology. Vol. I: Endocrinology, V. H. T. James, ed., pp. 205-209, Excerpta Medica, Amsterdam

Owman, C., and N. -O. Sjostrand (1965) Short adrenergic neurons and catecholamine-containing cells in vas deferens and accessory male genita glands of different mammals. Z. Zellforsch. Mikrosk Anat. 66: 300-320

Owman, C., N. -O. Sjoberg, and G. Swedin (1971) Histochemical and chemical studies on pre- and postnatal development of the different systems of "short" and "long" adrenergic neurons in peripheral organs of the rat. Z. Zellforsch. Mikrosk. Anat. 116: 319-341.

Owman, C., N. -O. Sjoberg, and N. -O. Sjostrand (1974) Short adrenergic neurons, a peripheral neuroendocrine mechanism. In Amine Fluorescence Histochemistry, M. Fugwara and C. Tanaka, eds., pp. 47-66, Igaku Shoin, Tokyo

Owman, C., P. Alm, and N. -O. Sjoberg (1983) Pelvic autonomic ganglia Structure, transmitters, function and steroid influence. In Autonomic Ganglia, L. -G. Elfvin, ed., pp. 125-143, John Wiley \& Sons, Inc., New York.
Partanen, L., and A. Hervonen (1979) The formaldehyde-induced fluores cence of the developing hypogastric (main pelvic) ganglion of the rat Short adrenergic neurons and the effect of testosterone. Histochemistry 62: $249-258$

Patterson, P. H. (1978) Environmental determination of autonomic neurotransmitter functions. Annu. Rev. Neurosci. 1: 1-17.

Patterson, P. H., and L. L. Y. Chun (1977) The induction of acetylcholine synthesis in primary cultures of dissociated rat sympathetic neurons. I Effects of conditioned medium. Dev. Biol. 56: 263-280.

Rybarczyk, K. E., H. A. Baker, J. P. Burke, B. K. Hartman, and L. S. Van Orden (1976) Histochemical and immunocytochemical identification of catecholamines, dopamine-B-hydroxylase and phenylethanolamine- $N$ methyltransferase. In SIF Cells, O. Eranko, ed., pp. 68-81, United States Government Printing Office, Washington, D.C.

Sieber-Blum, M. F. Sieber, and K. M. Yamada (1981) Cellular fibronectin promotes adrenergic differentiation of quail neural crest cells in vitro. Exp. Cell Res. 133: 285-295.

Siegrist, G., F. de Ribaupierre, M. Dolivo, and C. Rouiller (1966) Les cellules chromaffines des ganglions cervicaux superieurs du rat. J. Microsc. 5 $791-794$.

Siegrist, G., M. Dolivo, Y. Dunant, G. Foraglou-Kerameus, F. de Ribaupierre and $C$. Rouiller (1968) Ultrastructure and function of the chromaffin cells in the superior cervical ganglion of the rat. J. Ultrastruct. Res. 25: $381-$ 407 .

Sjostrand, N. O., and G. Swedin (1976) Influence of age, growth, castration and testosterone treatment on the noradrenaline levels of the ductus deferens and the auxiliary male reproductive glands of the rat. Acta Physiol. Scand. 98: 323-338.

Smith, J., and M. Fauquet (1984) Glucocorticoids stimulate adrenergic differentiation in cultures of migrating and premigralory neural crest. $J$ Neurosci. 4: 2160-2172.

Taxi, J. (1979) The chromaffin and chromaffin-like cells in the autonomic nervous system. Int. Rev. Cytol. 57: 283-343

Taxi, J., M. Derer, and A. Domich (1983) Morphology and histophysiology of SIF cells. In Autonomic Ganglia, L. -G. Elfvin, ed., pp. 67-95, John Wiley \& Sons, Inc. New York

Teitelman, G., T. H. Joh, and D. J. Reis (1978) Transient expression of a noradrenergic phenotype in cells of the rat embryonic gut. Brain Res. 158: $229-234$

Teitelman, G., H. Baker, T. H. Joh, and D. J. Reis (1979) Appearance of catechnlamine-synthesizing enzymes during development of rat sympathetic nervous system: Possible role of tissue environment. Proc. Natl. Acad. Sci. U. S. A. 76: 509-513.

Tischler, A. S., R. A. deLellis, B. Biales, G. Nunnemacher, V. Carabba, and H. J. Wolfe (1980) Nerve growth factor-induced neurite outgrowth from normal human chromaffin cells. Lab. Invest. 43: 399-409

Tomasulo, J. A., F. M. Sansone, and R. J. Mclsaac (1982) Variation iri riumber of small intensely flourescent cells (SIF cells) in rat superior cervical ganglia. Exp. Neurol. 78: 83-90.

Unsicker, K., B. Krisch, U. Otten, and H. Thoenen (1978) Nerve growth factor-induced fiber outgrowth from isolated rat adrenal chromaffin cells: Impairment by glucocorticoids. Proc. Natl. Acad. Sci. U. S. A. 75: 3498 3502 .

Wechsler, W., and L. Schmekel (1967) Electronmikroskopische Untersuchungen der Entwicklung der vegetativen (Grenzstrang-) und spinalen Ganglien bei Gallus domesticus. Acta Neuroveg. 30: 427-444.

Williams, T. H., and S. L. Palay (1969) Ultrastructure of the small neurons in the superior cervical ganglion. Brain Res. 15: 17-34.

Williams, T. H. W. (1967) Electron microscope evidence for an autonomic interneuron. Nature 214: 309-310.

Yokota, R. (1973) The granule-containing cell somata in the superior cervical ganglion of the rat, as studied by a serial sampling method for electron microscopy. Z. Zellforsch. 141: 331-345.

Zaimis, E., L. Berk, and B. A. Callingham (1965) Morphological biochemica and functional changes in the sympathetic nervous system of rats treated with nerve growth factor-antiserum. Nature 206: 1220-1222. 